\title{
A "PUBLIC ASSETS" THEORY OF LAWYERS' PRO BONO OBLIGATIONS
}

\author{
STEVEN LUBET $†$ \& \\ CATHRYN STEWART $\dagger \dagger$
}

\section{TABLE OF CONTENTS}

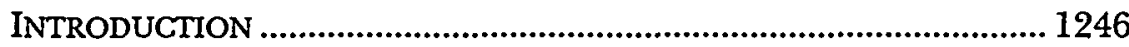

A. Mandatory Pro Bono Obligations............................................... 1247

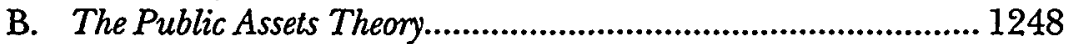

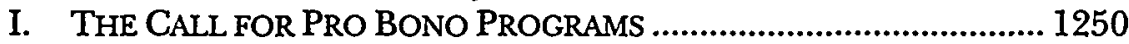

A. Crisis In Legal Services......................................................... 1253

1. Lawyers' Role ............................................................. 1254

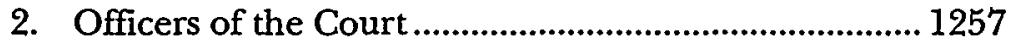

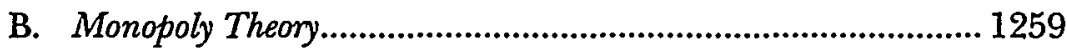

C. Moral Obligation and Good Will ............................................... 1261

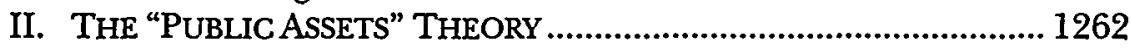

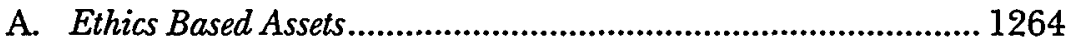

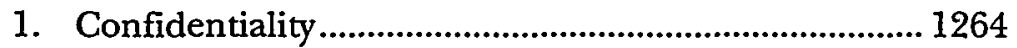

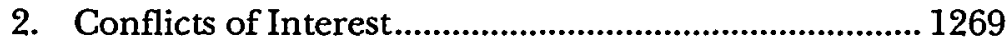

B. Evidence-Based Assets............................................................. 1272

1. Attorney-Client Privilege ................................................ 1272

2. Work Product Doctrine ................................................ 1276

3. Costs of Evidentiary Privileges ...................................... 1279

a. Suppression of Truth..................................................... 1279

b. Increased Litigation Costs.......................................... 1281

c. Work Shifting to High-Priced Providers .......................... 1282

C. Summary .............................................................................. 1284

III. CONDITIONED ACCESS TO INFORMATION-ASSETS:

$\dagger$ Professor of Law, Northwestern University School of Law. We are grateful to Mary Coombs, Thomas Geraghty, Gary Lawson, Laura Lin, Fred McChesney, Rayman Solomon, Timothy Terrell and Fred Zacharias for their helpful comments on earlier drafts. We profited as well from the observations of workshop participants at Northwestern University, Emory University and the University of Illinois. This project was supported by generous grants from the Stanton R. Clinton Faculty Fund and the Morris R. Shapiro Endowment of the Northwestern University School of Law.

Finally, this article is dedicated to Lawrence Marshall, our friend and colleague, who embodies the spirit of pro bono practice.

H Associate, Epstein Zaideman \& Esrig. My thanks to Thomas Crawford for his unending support and encouragement. 


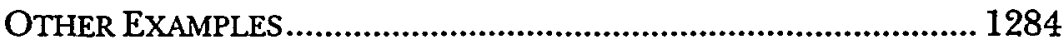

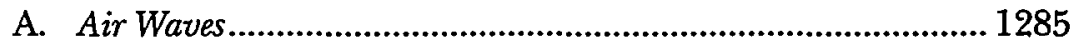

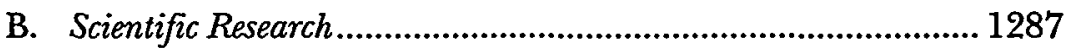

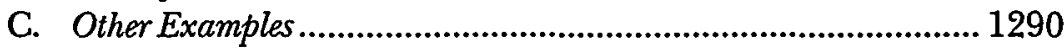

IV. ARGUMENTS AGAINST MANDATORY PRO BONO PLANS ................. 1292

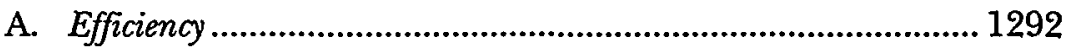

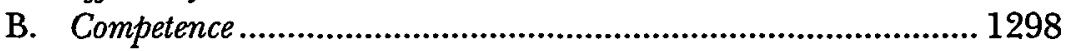

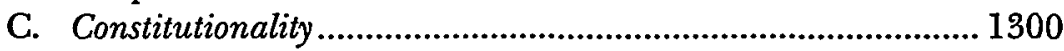

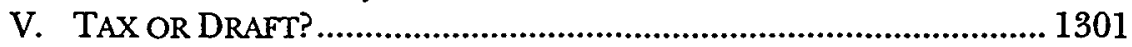

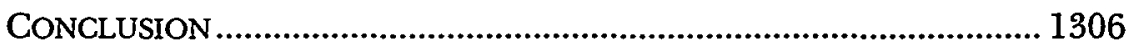

\section{INTRODUCTION}

This Article presents a new theory of lawyers' obligations to provide free representation to the poor. In putting forward our views, we hope to break, or at least loosen, the current logjam in the debate over mandatory pro bono programs. Much of the discussion has been hampered by a lack of common ground. Pro bono advocates argue from need, responsibility, even morality, while opponents emphasize equally compelling principles of autonomy and freedom. Framed often as a contest between polar positions, there is little perceived room for compromise. If pro bono representation is a bedrock professional duty, then lawyers simply have to do it. Period. On the other hand, if it is an unwarranted encroachment on personal freedom, then mandatory programs must be staunchly resisted. Period.

We believe, however, that there is a way to shift the discourse away from absolutes and into more fruitful territory. As we will develop in the course of this Article, our "public assets" theory posits that lawyers are, at least in part, concessionaires. Attorneys are granted exclusive access to certain publicly created commodities which they subsequently provide (at a price) to clients. Thus, a portion of lawyers' income is directly attributable to their ability to market "lawyercommodities" that have been provided to them, at no charge, by the public. The exaction of a pro bono obligation can therefore be seen as a simple recapture of some of the profit derived from access to this asset.

In this Article we set out four publicly created lawyer-assets, each of which provides rights of privacy and information control. We submit that clients pay their lawyers for access to secrecy, which comes in the form of ethics-based duties such as confidentiality and conflicts protection, as well as the evidence-based protections of the attorney- 
client privilege and the work product doctrine. If we are correct that secrecy is a commodity, of which lawyers are the vendors but not the creators, then the conversation may shift to consideration of the consequences of lawyers' use of that commodity. In other words, pro bono duty becomes the equivalent of a user fee-neither a moral imperative nor an assault on individual rights and freedoms, but rather a familiar and legitimate consequence of economic relationships.

We advance this position as a first step, recognizing that much will remain to be debated even if our arguments are as persuasive as we hope them to be. How extensively do lawyers exploit privacycommodities? In what ways should lawyers be treated differently from other professionals and merchants who also utilize public assets? What would constitute fair recapture of the benefits lawyers realize from their ability to "sell" secrecy?

\section{A. Mandatory Pro Bono Obligations}

For over a century, leaders of the legal profession have stressed the need for lawyers to contribute their time and energy to the needs of the underserved and disadvantaged. Increasingly, proposals have come in the form of mandatory pro bono plans, which would require every lawyer to devote a specified number of hours annually to representing poor or middle-income clients. While luminaries ranging from a president of the American Bar Association ${ }^{1}$ to a Justice of the United States Supreme Court ${ }^{2}$ have exerted their moral authority in support of one plan or another, to date no state has adopted a comprehensive pro bono requirement. $^{3}$

The principled opposition to mandatory pro bono plans is based

' See Talbot D'Alemberte, Calling the Roll of Lauyers: Providing Service to All, 21 CAP. U. L. REV. 861, 863 (1992) ("[T] he real problem for American lawyers today ... is to solve the problem of equal access to justice.").

2 See Sandra Day O'Connor, Meeting the Demand for Pro Bono Services, 2 B.U. PuB. INT. L.J. I, 1 (1992) (suggesting that lawyers should be "ashamed ... of how we are responding to the needs of people who can't afford to pay for our services").

${ }^{3}$ A number of states, including Florida, Texas, Hawaii and New York, have taken steps to motivate lawyers to render more pro bono services, but none have gone so far as to enact an actual requirement. See Ruth Singleton, Bar Leaders Urge Mandatory Service, Reporting of Hours, NAT'L L.J., Mar. 10, 1997, at A23.

Florida, for example, adopted a rule in 1993 requiring lawyers to report annually the number of hours spent on pro bono practice. Although a federal court recently upheld the constitutionality of the requirement, the rule itself was suspended by the Florida Supreme Court almost immediately after its adoption. See id. 
upon considerations of fairness, efficiency and freedom of choice. ${ }^{4}$ These are important objections. Indeed, we recognize that the standard pro-pro bono arguments have been inadequate to the task of refuting the major intellectual criticisms.

The typical argument in favor of mandatory pro bono obligations begins with a statement of need: the poor and middle classes are dramatically underserved by lawyers. Next comes a statement of duty based, variously, on moral obligation, necessity or the so-called "monopoly theory." While the need for broader legal services is relatively easy to demonstrate, it has not been rigorously established that individual lawyers should bear the burden of meeting that need. Obligations premised on moral duty or necessity ultimately fail analytically because it cannot be shown persuasively that only lawyers should bear the social responsibility of fulfilling unmet legal needs. The monopoly theory seeks to provide just that linchpin, but it fails empirically. With nearly one million American lawyers in sharp competition with one another, ${ }^{6}$ it is difficult to show that there is a monopoly in any conventional sense.

We believe that lawyers should be required to devote a portion of their professional time to pro bono representation. Despite the weaknesses of prior pro bono arguments, we are optimistic that our "public commodities" theory will prove both intellectually and empirically rigorous in establishing the analytical basis for that duty.

\section{B. The Public Assets Theory}

In brief, the public assets theory is based upon the concept that every lawyer profits from the sale to clients of certain publicly created assets. A mandatory pro bono plan, therefore, should be regarded as

${ }^{4}$ See In re Emergency Delivery of Legal Servs., 432 So. 2d 39, 41 (Fla. 1983) (rejecting adoption of mandatory pro bono program and noting that "a person's voluntary service ... has to come from within the soul of that person"); Debra Burke et al., Pro Bono Publico: Issues and Implications, 26 LOY. U. CHI. L.J. 61, 83 (1994) (arguing that greater efficiency is achieved by donating money, as opposed to services); Timothy P. Terrell \& James H. Wildman, Rethinking "Professionalism," 41 EMORY L.J. 403, 430 (1992) (noting that considerations of professionalism require that the bar facilitate pro bono efforts, but not mandate individual obligations).

5 Attorneys may also resist pro bono plans on the basis of self-interest. They do not want to be told what to do, and they do not want to divert effort and attention away from their paying clients. We recognize that no amount or quality of argument will win over lawyers who object to pro bono plans on purely monetary grounds.

${ }^{6}$ As of June 1996, there were 946,499 lawyers in the United States. American Bar Association, Membership Ranking by State (June 1996). 
comparable to an in-kind user fee, severance or commission, returned to the public in exchange for the right to exploit a public resource.

What do lawyers sell? For the most part, counsel's services consist of the attorney's own accumulated human capital: knowledge, skill, education, experience, reputation, discretion and good judgment. ${ }^{7}$ Consider these and similar services to be a bundle of commodities, sold to the client as a package, each supplying a benefit to the client, and each justifying a portion of the lawyer's fee.

In addition to the lawyer's self-generated assets, attorneys also sell certain publicly created assets. Chief among these are certain rights of confidentiality and enforceable duties of loyalty. ${ }^{8}$ Unlike the lawyer's human capital, these assets were created by the public, either through statutes, judicial codes of conduct, or the operation of common law. While it is generally understood that these resources were conceived primarily to confer benefits upon clients, it is certain that they also enhance the value of lawyers' services, and that they therefore increase lawyers' fees.' In other words, all lawyers constantly engage in the sale of publicly created resources. Because the lawyers themselves did nothing to create the assets, but are nonetheless able to sell them at a profit, economists would refer to this as the extraction of rents or quasi-rents. ${ }^{10}$ Our argument for a mandatory pro bono obligation is that the public, having created the assets and assigned them to lawyers, is entitled to recapture some portion of the rent in the form of in-kind services.

Part I surveys the principal arguments that have been put forth in favor of mandatory pro bono plans, critiquing them and demonstrating their analytic flaws and persuasive failings. Part II describes and develops our own "public assets" theory, which we think is free from many of the shortcomings of the other approaches. Part III provides examples of other "in-kind" duties imposed in consequence of the

${ }^{7}$ See ANThony Kronman, The Lost Lawyer: FaILING Ideals of THE LeGal PROFESSION 109-62 (1993) (discussing the attributes that make for a successful attorney). Regarding lawyers' investment in "reputation capital," see Jonathan R. Macey \& Geoffrey P. Miller, Reflections on Professional Responsibility in a Regulatory State, 63 GEO. WASH. L. REV. 1105, 1108 (1995) ("Lawyers make investments in reputation capital by attending prestigious law schools and by joining prestigious law firms.").

${ }^{8}$ See Macey \& Miller, supra note 7, at 1108 (noting that ethical assurances make clients more willing to hire lawyers).

${ }^{9}$ See id. at 1105 (arguing that rules governing client confidentiality and conflicts of interest further the economic interests of the legal profession).

${ }^{10}$ See Charles Hulter \& Frank Wykoff, Issues in the Measurement of Economic Depreciation: Introductory Remarks, 34 ECON. INQUIRY 10 (1996). 
use of public assets. Part IV addresses the previous arguments against mandatory pro bono plans, explaining that they are insufficient to overcome the "public assets" theory. Finally, Part V deals briefly with the "tax or draft" question: Must pro bono obligations be met by providing personal services, or should there be a "buy out" provision?

\section{The CALl For Pro Bono Programs}

The ideal of law practice as public service is as old as the profession itself. For many, altruism has always been the defining feature of true professionalism." Nonetheless, the early development of professional standards did not include required pro bono services. The 1908 Canons of Professional Ethics make no mention of a general duty to provide free services. ${ }^{12}$ The 1969 Code of Professional Responsibility addresses the issue, but only through exhortation: "Every lawyer, regardless of professional prominence or professional workload, should find time to participate in serving the disadvantaged."13

In 1977, the American Bar Association established a special Commission on Professional Standards, assigned to draft a new set of ethics rules. Chaired by the late Robert Kutak, the Commission eventually produced the Model Rules of Professional Conduct, which have since been adopted in whole or part by over forty United States jurisdictions. $^{14}$ In an early draft, the Kutak Commission proposed that

"See, e.g., ABA COMM'N ON PROFESSIONALISM, “... IN THE SPIRIT OF PUBLIC SERVICE": A BLUEPRINT FOR REKINDLING LAWYER PROFESSIONALISM 15 (1986) [hereinafter IN THE SPIRIT OF PUBLIC SERVICE] (suggesting that members of the bar should increase participation in pro bono activities); Rayman L. Solomon, Five Crises or One: The Concept of Legal Professionalism, 1925-1960, in LAWYERS' IDEALS/LAWYERS' PRACTICES: TRANSFORMATIONS IN THE AMERICAN LEGAL PROFESSION 144, 146-47 (Robert L. Nelson et al. eds., 1992) [hereinafter LAWYERS' IDEALS/LAWYERS' PRACTICES] (discussing altruism as an aspect of professionalism).

12 See Canons of Professional Ethics (1908). The closest provision is found in Canon 4, titled "When Counsel for An Indigent Prisoner": "A lawyer assigned as counsel for an indigent prisoner ought not to ask to be excused for any trivial reason, and should always exert his best efforts in his behalf."

${ }_{13}$ MODEL CODE OF PROFESSIONAL RESPONSIBILITY EC 2-25 (1969). The drafters of the Model Code considered the "Ethical Considerations" to be "aspirational in character and [to] represent the objectives toward which every member of the profession should strive." Id. at 1 . Only the "Disciplinary Rules" were meant to be enforceable and "mandatory in character." Id. None of the Disciplinary Rules mention pro bono obligations.

14 ABA/BNA LAWYERS' MANUAL ON PROFEssional Conduct 01:3-4 (1984 \& Supp. 1995). For a social and political history of the Kutak Commission debates, see Theodore Schneyer, Professionalism as Politics: The Making of a Modern Legal Ethics Code, in LAWYERS' IDEALS/LAWYERS' PRACTICES, supra note 11, at 95. 
every lawyer, as a condition of membership in the bar, be required to provide forty hours of pro bono services each year (or the financial equivalent). ${ }^{15}$ Prompted by heavy opposition from members of the bar, this rule was watered down through successive stages of the process until the ABA's House of Delegates finally adopted a purely voluntary rule: "A lawyer should render public interest legal service." The pro bono provision is the only rule in the entire Model Rules that is not mandatory. ${ }^{17}$

Notwithstanding the compromise nature of the eventual Model Rule, ${ }^{18}$ the leadership of the American Bar Association continued to identify a need for lawyers to provide pro bono services. Three years following the adoption of the Model Rules, the ABA's Commission on Professionalism ("Stanley Commission") issued a report stressing the importance of lawyers' participation in pro bono activities. ${ }^{19}$ In 1991, the House of Delegates reaffirmed the ABA's goal of promoting "meaningful access to legal representation ... for all persons regardless of their economic or social condition."20 In 1992, ABA President Talbot D'Alemberte stated that among his top priorities was to "expand the numerous pro bono legal services programs throughout the country."

In 1993, the American Bar Association formally revisited the question of pro bono obligations when the Standing Committee on Lawyers' Public Service Responsibility submitted to the House of Delegates a proposed amendment to Model Rule 6.1. The report accompanying the proposal emphasized the "current crisis in the delivery of legal services to the poor. ${ }^{22}$ The Committee reasoned that, while members of the bar alone cannot be expected to solve this serv-

${ }^{15}$ See Schneyer, supra note 14 at 113-14.

${ }^{16}$ MODEl RULES OF PROFESSIONAL CONDUCT Rule 6.1 (1983) (emphasis added).

17 The comment makes it clear that there was to be no actual requirement of pro bono services. "This Rule... is not intended to be enforced through disciplinary process." Id. at Rule $6.1 \mathrm{cmt}$.

${ }^{18}$ See Joseph L. Torres \& Mildred R. Stansky, In Support of a Mandatory Public Service Obligation, 29 EMORY L.J. 997, 999-1001 (1980) (discussing the disagreement in the legal community over various Model Rule drafts addressing pro bono practices).

19 See IN THE SPIRTT OF PUblic SERVICE, supra note 11 , at 47.

${ }^{20}$ Robert MacCrate, "The Lost Lawyer" Regained: The Abiding Values of the Legal Profession, 100 DICK. L. REV. 587, 610 (1996).

${ }^{21}$ Talbot D'Alemberte, Lawyers Have a Duty to Serve the Poor, JuDGES' J., Summer 1992 , at $18,19$.

${ }^{22}$ ABA Standing Comm. on Lawyers' Public Service Responsibility, Report to the House of Delegates, at 6 (Feb. 1993) [hereinafter Report to House of Delegates] (on file with the University of Pennsylvania Law Review). 
ice crisis, lawyers should be called upon to increase their pro bono activities to help meet the needs of the disadvantaged. ${ }^{23}$ Although the House of Delegates did not adopt the Committee's report, it did enact the amendment to Model Rule 6.1, clarifying the expectation of lawyers' services, while maintaining the precatory nature of the rule: "[a] lawyer should aspire to render at least (50) hours of pro bono publico legal services per year. ${ }^{24}$

Thus, for at least the last twenty years the organized bar has been simultaneously pressing lawyers to expand their pro bono efforts, while steadfastly avoiding any actual requirement that they do so. The cause of public service has great institutional support, both at the national and state levels. ${ }^{25}$ We believe, along with many others, that a certain level of pro bono involvement should be a requisite of bar membership. ${ }^{26}$ It is clear, however, that the arguments in favor of mandatory pro bono plans have thus far been unpersuasive-no jurisdiction, and no bar association, have adopted such a plan.

In our view, one reason for this failure to act has been the inadequacy of the standard arguments in favor of mandatory pro bono requirements. While the pro-pro bono rationales have been morally appealing, they have lacked the quality of intellectual infrastructure that would allow them to overcome principled opposition.

We now turn to a critique of the traditional pro bono arguments.

23 See id.

${ }^{24}$ MODEL RULES OF PROFESSIONAL CONDUCT Rule 6.1 (1993). The new Rule 6.1 additionally states that lawyers should provide "a substantial majority of the (50) hours of legal services without fee or expectation of fee." It also defines the classes of persons and organizations that might be the recipient of pro bono services, and concludes by stating that "a lawyer should voluntarily contribute financial support for organizations that provide legal services to persons of limited means." Id.

${ }^{25}$ See, e.g., Committee to Improve the Availability of Legal Services, Final Paper to the Chief Judge of New York, 19 HOFSTRA L. REV. 755, 756 (1991) [hereinafter Marrero Committee Report] (recommending "a comprehensive program of remedial actions" to address the "unmet need for civil legal services among the poor in New York state").

${ }^{26}$ According to a 1994 survey, American lawyers bill an average of 2500 hours per year. See Thom Weidlich, In World Legal Bills, U.S. Wins on Hours, NAT'L L.J., Oct. 17, 1994, at A5. Amended Rule 6.1 of the Model Rules of Professional Conduct recommends at least $\mathbf{5 0}$ hours per year of pro bono work, which is therefore roughly two percent of most lawyers' workload. See MODEL RULES OF PROFESSIONAL CONDUCT Rule 6.1 (1993). New York's Marrero Commission recommended 20 hours per year, or less than one percent of the typical lawyer's output. See Marrero Committee Report, supra note 25, at 756 (proposing a requirement that lawyers devote a minimum of 40 hours every two years to pro bono representation). We take no position on which measure is preferable, though we think that the Marrero Report and the Model Rule probably lie at the ends of the appropriate continuum. 


\section{A. Crisis In Legal Services}

Most arguments in favor of pro bono plans proceed from the premise that there is a "legal crisis" in the United States. And indeed, there can be little doubt that the legal needs of the poor and middle classes have been drastically underserved. By one estimate, eighty percent of the legal needs of the poor go unmet, ${ }^{27}$ and a significant percentage of middle class families are also unable to afford basic legal services. ${ }^{28}$ Attempts to deal with this problem through voluntary plans have been essentially unsuccessful. ${ }^{29}$

At the same time, it appears that governmental support for legal services is on a steady downward trend. In 1993, when Model Rule 6.1 was amended, federal support for the Legal Services Corporation stood at $\$ 328$ million. $^{30}$ By 1996 , the budget for the Legal Services Corporation had decreased to $\$ 278$ million, ${ }^{31}$ a cut of over fifteen percent, with further reductions looming on the horizon. ${ }^{32}$

Whether one accepts or rejects the "crisis" designation, ${ }^{33}$ it seems

${ }^{27}$ See Report to House of Delegates, supra note 22 , at 6 , and reports cited therein.

${ }^{28}$ See Torres \& Stansky, supra note 18, at 1023-24 n.113 (discussing an ABA committee report which found that "lawyers are consulted for slightly less than a third of the problems encountered that reasonably could be called legal problems"' (quoting B. CURRAN, THE LEGal NEedS OF THE PUBLIC 261 (1977))).

${ }^{29}$ Despite the admonition of Model Rule 6.1, there is no indication that lawyers have substantially increased their pro bono hours. Recent debates in Congress over funding for legal services programs reveal that poor and middle class families are still unable to obtain representation. See 141 CONG. REC. S14,612 (daily ed. Sept. 29, 1995) (statement of Sen. Kennedy) (noting that legal needs studies from various states show that only $15-20 \%$ of civil legal needs of the poor are being met by current funding levels). No state has yet adopted a mandatory pro bono plan, although several have instituted voluntary plans. As admirable as they may be, there is no indication that any of these voluntary plans have made significant inroads into satisfying the unmet needs of the disadvantaged. See Marrero Committee Report, supra note 25, at 824 (noting that despite the fact that bar associations nationwide have made concerted efforts to encourage voluntary services, only about $10 \%$ of all attorneys in New York engage in pro bono work geared toward the poor); Michael Millemann, Mandatory Pro Bono in Civil Cases: A Partial Answer to the Right Question, 49 MD. L. REV. 18, 58 (1990) (noting that voluntary programs in Maryland have not met the need for legal services of the poor).

${ }^{30}$ Report to Honse of Delegates, supra note 22, at 7 (citing Lillian Johnson, Project Advisory Group, Testimony Before the ABA Standing Committee on Legal Aid and Indigent Defendants on Funding for the Legal Services Corporation for FY 1993 (Nov. 2, 1991) and Attachment).

31 See Payment to the Legal Services Corporation, Pub. L. No. 104-134, 110 Stat. $1321-50$ (1996).

${ }^{52}$ See Claudia MacLachlan, LSC Fights for Its Life; Funding May Be Cut 50\%, NAT'L L.J., July 29, 1996, at Al4.

${ }^{33}$ Certainly some of the indicators that might commonly be used to connote a crisis-threats to health, life, safety, property or general welfare-are implicated by the 
amply clear that neither private efforts nor public funding will be adequate at any time in the foreseeable future to provide essential legal services for Americans of limited means. It has often been suggested that lawyers, individually or as a profession, have a special duty to attempt to ameliorate this problem. ${ }^{34}$ The argument from need, in all of its variations, inevitably stands or falls on the establishment of such a special duty.

\section{Lawyers' Role}

A frequent argument in favor of mandatory pro bono plans is that lawyers stand in a unique position to alleviate the crisis. Because lawyers are indispensable to the legal process, proponents of this view reason that lawyers have an obligation to make sure the process works. ${ }^{35}$ Since the process is based on the idea of adequate individual representation, the conclusion is that lawyers must make such representation available, even if that means serving for no fee. ${ }^{36}$

The gap in the argument lies in the transition from need to duty. True, there is a need. And true, only lawyers can provide the necessary professional skills to meet the need. But why must their service be compelled, and at no fee? With the flight of jobs to distant suburbs, coupled with the decline of mass transit, many of the urban

inability of so many people to obtain legal services. On the other hand, the "crisis" characterization has also been rejected as overstated or unjustified. See Marrero Committee Report, supra note 25, at 848 (statement of committee member Sol Neil Corbin, dissenting from the committee's recommendation and denying the existence of crisis); Jonathan R. Macey, Mandatory Pro Bono: Comfort for the Poor or Welfare for the Rich?, 77 CORNELL L. REV. 1115, 1116 (1992) (arguing that poor persons rationally choose not to expend limited resources on hiring lawyers).

${ }^{34}$ See, e.g., Report to House of Delegates, supra note 22, at 6 (discussing lawyers' duty to address legal crises).

${ }^{35}$ See, e.g., Terrell \& Wildman, supra note 4, at 422-23 (noting that the special position of law in American society dictates special obligations for the legal profession); Torres \& Stansky, supra note 18, at 1026 ("[F]or better or worse, justice under the law, as society has come to regard and require, cannot be done without lawyers.").

${ }^{36}$ Even when arguing that the government bears part of the burden to provide access to the judicial system, it is posited that lawyers bear an independent responsibility. See Millemann, supra note 29, at 12-13 ("[A] ttorneys must take the lead in helping to serve the legal needs of the poor as a prerequisite to seeking additional government support."); see also Stephen T. Maher, No Bono: The Efforts of the Supreme Conurt of Florida to Promote the Full Availability of Legal Services, 41 U. MIAMI L. REV. 973, 975 (1987) (noting that although mandatory pro bono seems extreme, many have concluded that it is the only effective way to meet the legal needs of the poor); Torres \& Stansky, supra note 18, at 1025 ("Not only are lawyers better prepared ... to deal with the pervasiveness and complexity that is the law ... but they are an element indispensable to the legal process." (footnote omitted)). 
poor are certainly facing a transportation crisis. Nonetheless, the "special role" of taxi and limousine drivers (all licensed professionals) is not thought to compel a mandatory shuttle service. The crisis in medical services for the poor is addressed through tax-supported programs such as Medicaid and the public health service. While only medical professionals can supply the necessary care, their "special role" is not thought to require them to work for free. ${ }^{37}$ Thus, "need" is a necessary, but not sufficient, condition for the establishment of mandatory pro bono duties. ${ }^{38}$ Consequently, an argument strictly from necessity must fail: lawyers do not have to solve the problem simply because they can.

Over the years, pro bono proponents have attempted, with little success, to supply the necessary link between need and duty, typically by expanding or expounding on the unique position of lawyers in American society. Chief Judge Harry T. Edwards of the District of Columbia Circuit advances one of the most cogent arguments. ${ }^{39}$ Judge Edwards points out that because of the highly legalized nature of our society, lawyers are "essential to virtually all projects of social import." This gives lawyers "disproportionate social and political power," which can only be legitimated by assuming an affirmative duty to "cultivate professional public spiritedness." therefore believes that lawyers have a social and moral duty to represent those people who do not have sufficient access to legal services. ${ }^{42}$

Judge Edwards's position provides a compelling rationale for those who accept "public spiritedness" as an essential attribute of professionalism. For others, however, there is no evident relationship be-

${ }^{37}$ Indeed, physicians in private practice are not even required to accept Medicare and Medicaid patients, should they deem the level of reimbursement too low. $C$. COUNCIL ON ETHICAL AND JUDICIAL AFFAIRS, AMERICAN MED. ASSOC., Caring for the Poor, 269 JAMA 2533, 2535 (1993) ("While the majority of physicians do provide free or reduced fee practices, as high as one-quarter to one-third of practitioners may fail to provide services to the poor.").

${ }^{38}$ But cf. Maher, supra note 36 , at 975 (arguing that mandatory pro bono is not unreasonable in light of the massive legal needs of the poor).

${ }^{39}$ Harry T. Edwards, A Lawyer's Duty to Serve the Public Good, 65 N.Y.U. L. REV. 1148 (1990).

Id. at 1156.

${ }^{41}$ Id.

42 See id. at 1150, 1160; see also Steven Rosenfeld, Mandatory Pro Bono: Historical and Constitutional Perspectives, 2 CARDOZO L. REV. 255, 281 (1981) (stating that although courts and legislatures have created a host of procedural rights and substantive remedies for the poor, "those advances become empty promises without lawyers to vindicate the rights and pursue the remedies"). 
tween social and political power and an obligation to serve the poor. Why must individual lawyers, at their own expense, fulfill the empty promises made by courts and legislatures? Judge Edwards's argument is ultimately moral in nature-convincing to the already converted, but lacking sufficient basis on which to compel the unconvinced. ${ }^{4}$

A similar theme is found in the report of New York's Committee to Improve the Availability of Legal Services (the "Marrero Committee"), which is one of the most thorough treatments to date of the mandatory pro bono issue. In 1988, the Chief Judge of the New York Court of Appeals appointed a committee to study the legal needs of the poor and to create a plan to address those needs. ${ }^{44}$ Chaired by Victor Marrero, the committee presented a report calling for a statewide requirement that all practicing attorneys in New York provide at least forty hours of pro bono service every two years. ${ }^{45}$

The Marrero Committee proposal generated substantial controversy and opposition, including two dissenting statements from members of the committee. ${ }^{46}$ In his letter accompanying the committee report, Chairman Marrero responded to the opposition by explaining the bases for the committee's conclusions. First, Marrero underlined the committee's belief that the most effective way to address the shortage of legal services was through the imposition of a pro bono requirement. ${ }^{47}$ Second, he stated that the committee was "satisfied that there is adequate historical, ethical, and legal basis" for its conclusion that lawyers' "special role" creates a pro bono duty to the legal system. $^{48}$

Again we see the conflation of need and duty. This leads to the failure to come to grips with the argument that it is not the obligation of individual lawyers to solve social problems. While it is no doubt ef-

43 See, e.g., Greg Stevens, Note, Forcing Attomeys to Represent Indigent Civil Litigants: The Problems and Some Proposals, 18 U. MICH. J.L. REFORM 767 (1985) (arguing that the responsibility to provide legal services to the poor should not be placed on members of the bar).

${ }^{44}$ See Sol Wachtler, Symposium on Mandatory Pro Bono: Introduction, 19 HOFSTRA L. REV. 739 (1991).

${ }^{45}$ See Marrero Committee Report, supra note 25, at 770, 793.

${ }^{46}$ See id. at 847 (statement of Sol Neil Corbin). Corbin found the evidence insufficient to demonstrate that a legal crisis actually existed in New York, therefore concluding that it was inappropriate to compel lawyers to render free services. See id; see also id. at 850 (statement of Robert B. Fiske, Jr.) (arguing that more attention should be focused on increasing voluntary pro bono before further consideration of mandatory requirements).

\footnotetext{
Id. at 757.

48 Id. at 757,770 .
} 
ficient to place that burden on attorneys, the majority of practitioners resist the notion that it is their responsibility to step in where the government has failed to act. ${ }^{49}$ As to the Marrero Committee's reliance on an "historical, ethical, and legal basis" for its recommendation, one need look no further than the Code of Professional Responsibility, cited as authority by the committee report, ${ }^{50}$ to realize the circularity of its argument. The drafters of the Model Code took pains to avoid providing an ethical or historical-much less legal-basis for mandatory pro bono programs. ${ }^{5 !}$

Thus, the Marrero Committee Report argues persuasively that New York should have a lawyers' pro bono program, but does not demonstrate why the program should be compulsory. In other words, the committee supposes a duty but does not establish one.

\section{Officers of the Court}

A further elaboration on the need/duty argument rests on lawyers' status as so-called "officers of the court, ${ }^{, 52}$ as evidenced by the fact that attorneys are sometimes obligated to accept court appointments in criminal cases. ${ }^{53}$ Unlike the necessity theory, the "officer of the court" theory is not based upon a posited obligation to serve the poor or to protect the constitutional rights of the accused. It is derived instead from a duty to assist the court in the administration of justice. Thus, court-appointed lawyers must serve not because they are needed by defendants, but rather because their defined role in the legal system requires that they come to the aid of judges when necessary. ${ }^{54}$ It is therefore unsurprising that most "officer of the

49 This proposition may be shown empirically. It is estimated that only about $10 \%$ of lawyers voluntarily engage in pro bono work. See supra note 29. It is obvious that, among the other $90 \%$, there has been no groundswell of support for mandatory programs.

See Marrero Committee Report, supra note 25, at 757.

31 See supra notes 18-24 and accompanying text.

${ }^{52}$ Marrero Committee Report, supra note 25, at 780.

53 For the origin and history of the obligation to accept court-appointed criminal cases, see United States v. Dillon, 346 F.2d 633 (9th Cir. 1965), cert. denied, 382 U.S. 978 (1966). Dillon is the most frequently cited case for the proposition that lawyers, because they are officers of the court, must serve without fee in court appointed cases.

${ }^{54}$ See id. at 635; Dolan v. United States, 351 F.2d 671, 672 (5th Cir. 1965) (affirming a lower court's dismissal of an attorney's claim for compensation for services rendered in representing an indigent client); Weiner v. Fulton County, 148 S.E.2d 143,147 (Ga. Ct. App.), cert. denied, 385 U.S. 958 (1966) (holding that serving as court appointed counsel is a duty of office). But see DeLisio v. Alaska Superior Court, 740 P.2d 437, 441 (Alaska 1987) (holding that the traditional/historical position of lawyer 
court" appointments arise in the context of criminal law, where the court's own duty may require the assignment of defense counsel.

The tenuous nature of the bar's obligation, however, is apparent from the fact that it has been so seldom invoked. Judges themselves do not really believe that all lawyers are their "officers," subject to compelled services without compensation. To be sure, American lawyers have a long custom of acknowledging court appointments, ${ }^{55}$ sometimes accepting them at significant personal sacrifice. ${ }^{56}$ Timothy Terrell and James Wildman have demonstrated, however, that lawyers' assistance to the courts stems from a tradition of commitment to professionalism, rather than from historical obligation. ${ }^{57}$ It is, as Robert Gordon puts it, part of the "ceremonial rhetoric" of the bar. ${ }^{58}$

Consequently, many courts have rejected the "officer of the court" concept. ${ }^{59}$ For example, in State ex rel. Scott $v$. Roper, ${ }^{60}$ the Missouri Supreme Court held that judges do not have the power to compel attorneys to represent civil litigants without compensation. The Roper court noted that the "officer of the court" designation for lawyers originated in English common law at a time when lawyers were granted special privileges, such as exemption from arrest and military duty, and certain immunities from suit. ${ }^{61}$ Since those privileges never obtained in the United States (and have long since atrophied even in England), the court observed that "officer of the court" is at best an empty title, "used as an incantation with little or no analysis of what the title means or why a particular result should flow from it. ${ }^{.62}$ The

as officer of the court cannot justify an otherwise unconstitutional taking of legal services without compensation).

${ }^{35}$ See, e.g., CanoNs of Professional and Judicial Ethics Canon 4 (1947) ("A lawyer assigned as counsel for an indigent prisoner ought not ask to be excused for any trivial reason, and should always exert his best efforts in his behalf.").

${ }^{56}$ The most famous, though fictional, example is found in Harper Lee's To KILL A MOCKINGBIRD (1960).

${ }^{57}$ See Terrell \& Wildman, supra note 4, at 432 (arguing that professionalism relates to "a core sense of self-respect among lawyers" and that such professionalism does exist within the bar).

${ }^{58}$ Robert W. Gordon, The Independence of Lawyers, 68 B.U. L. REV. 1, 24 (1988).

${ }^{59}$ See, e.g., DeLisio v. Alaska Superior Court, 740 P.2d 437, 441-42 (Alaska 1987); State ex rel. Scott v. Roper, 688 S.W.2d 757, 759-69 (Mo. 1985) (en banc). But see Bothwell v. Republic Tobacco Co., 912 F. Supp. 1221, 1231 (D. Neb. 1995) (magistrate judge) (finding that '[ $t]$ he critics' challenges to the validity of the office-of-the-court doctrine, while forceful, are flawed").

${ }^{60} 688$ S.W.2d 757 (Mo. 1985) (en banc).

${ }^{61}$ See id. at 765.

${ }^{62}$ Id. at 767 (citing Robert J. Martineau, The Attorney as an Officer of the Court: Time to Take the Gown Off the Bar, 35 S.C. L. REV. 541 (1984)). 
Roper court concluded, as do we, that no current obligation should be premised upon "this anachronism from English legal history. ${ }^{\text {63 }}$

\section{B. Monopoly Theory}

A second standard pro-pro bono argument rests on the premise that attorneys are granted an exclusive right to "operate the adversarial system that implements the law." As a consequence of this "statelicensed monopoly of lawyers over legal work," it is posited that lawyers may be required to provide free representation as a condition of licensure. ${ }^{65}$ Barriers to entry, though not as formidable as in the past, continue to operate in favor of lawyers by limiting the supply ${ }^{66}$ of legal services. ${ }^{67}$ Additionally, the organized bar perseveres in its efforts to prevent nonlawyers from engaging in activities that might be considered the practice of law. ${ }^{6 s}$

The standard monopoly argument is intellectually coherent, but factually weak. Licensure and monopoly are not entirely congruent concepts. Most states license barbers and beauticians, but those professions remain open to nearly all comers and consequently there is no shortage of competition among hair-cutters. On the other hand, many cities sharply limit the availability of taxicab medallions, ${ }^{69}$ result-

\footnotetext{
${ }^{63} I d$.

64 Robert L. Nelson \& David M. Trubek, Introduction to LAWYERS' IDEALS/LAWYERS' PRACTICES supra note 11 , at 1,7 .

${ }^{63}$ See Edwards, supra note 39, at 1159 (arguing that "the standard of public spiritedness requires every lawyer to remain committed, in word and deed, to preserve full and equal access to justice for all members of society"); Tigran W. Eldred \& Thomas Schoenherr, The Lawyer's Duty of Public Service: More Than Charity?, 96 W. VA. L. REV. 367, 399 (1993-1994) (stating that "every lawyer, as a condition of membership, has a professional responsibility to help assure that legal services are available to those in need"); Wachtler, supra note 44 , at 740 (discussing a mandatory pro bono requirement for all admitted attorneys in New York).

${ }^{66}$ See Millemann, supra note 29 , at 73-74.

67 See Jennifer Gerarda Brown, Rethinking "The Practice of Law, " 41 EMORY L.J. 451, 454 (1992) (noting barriers such as the expense of an ABA-approved law school, bar exams and state-by-state admissions).

${ }^{68}$ See id. at 454-55; Maher, supra note 36, at 976-82 (discussing relentless efforts of the Florida Bar Association to enjoin a nonlawyer from preparing legal forms for clients); Deborah L. Rhode, Policing the Professional Monopoly: A Constitutional and Empirical Analysis of Unauthorized Practice Prohibitions, 34 STAN. L. REV. 1, 19 (1981) (noting that in a majority of jurisdictions the organized bar is the only active enforcer of restrictions on law practice).

${ }^{69}$ See William Mellor, No Jobs, No Work, N.Y. TIMES, Aug. 31, 1996, at 21 (noting that the recent addition of 400 taxicab medallions in New York City brings total available medallions to 12,187-only 400 more than were allowed in 1937).
} 
ing in the virtual absence of price competition. ${ }^{70}$

The practice of law, though licensed, is simply not a monopoly or cartel in any conventional sense of that term. While attorneys of a bygone age may have successfully squelched competition and extracted monopoly rents from their clients, ${ }^{12}$ that is far from the case today. ${ }^{72}$ If anything, modern law practice is characterized by competition among lawyers and law firms. ${ }^{73}$ As Terrell and Wildman point out, the only requirement for admission to the bar is a passing score on the bar exam. ${ }^{74}$ With the proliferation of law schools, themselves now in sharp competition for students, ${ }^{75}$ there are no longer such formidable educational barriers to entry. As a result, the bar is now more economically, socially and racially diverse than at any point in history. ${ }^{76}$

Jonathan Macey compellingly argues that contemporary lawyers earn only "normal," nonmonopoly returns on their investments in human capital. ${ }^{77}$ The increase in competition, fueled in part by the deregulation of advertising ${ }^{78}$ and solicitation methods, ${ }^{79}$ confirms that the traditional concept of a professional monopoly lacks persuasive

${ }^{70}$ Cities also set maximum rates for cab fares. Due to the absence of competition, however, the legal maximum fare also becomes the de facto minimum. Cab drivers do not engage in price competition.

71 See Goldfarb v. Virginia State Bar, 421 U.S. 773, 781-83 (1975) (holding that bar association's minimum fee schedule violated $\S 1$ of the Sherman Act).

${ }^{72}$ See Macey, supra note 33, at 1121 (noting that "[i]f at any time in history the legal profession was a monopoly, it is not any longer").

${ }^{73}$ See Bates v. State Bar, 433 U.S. 350, 381-82 (1977) (holding restraints on lawyer price advertising unconstitutional); Kenneth Lasson, Lawyering Askew: Excesses in the Pursuit of Fees and Justice, 74 B.U. L. REV. 723, 741 (stating that following the Bates decision, "the number of lawyers who advertise has increased dramatically and their radio and television campaigns have become more aggressive").

${ }^{74}$ See Terrell \& Wildman, supra note 4, at 410-12 (contrasting the admission requirements of the bar of the past to the bar of today).

${ }^{75}$ See Ken Myers, With Fewer Applications and Jobs, Deans Shrink First Year Classes, NAT'L L.J., Feb. 26, 1996, at A16.

${ }^{76}$ See Valerie Fontaine, Progress Report: Women and People of Color in Legal Education and the Legal Profession, 6 HASTINGS WOMEN's L.J. 27 (1995); Dana Coleman, Minority Enrollment Climbs to 24\% at State Law Schools, N.J. LAW., May 1, 1995.

${ }_{77}$ Macey, supra note 33, at 1122.

${ }^{78}$ Zauderer v. Office of Disciplinary Counsel, 471 U.S. 626, 637-56 (1985) (holding that a newspaper advertisement soliciting injury victims is protected speech); Bates, 433 U.S. at $381-82$ (holding that advertising by lawyers is constitutionally protected commercial speech).

${ }^{79}$ See supra note 73; see also Peel v. Attorney Registration \& Disciplinary Comm'n, 496 U.S. 91, 106-11 (1990) (holding that a lawyer may advertise certifications); Shapero v. Kentucky Bar Ass'n, 486 U.S. 466, 478-80 (1988) (allowing direct mail solicitation). 
force.

\section{Moral Obligation and Good Will}

Needless to say, invocations of morality, civics and general notions of professionalism are insufficient to support the imposition of a mandatory pro bono program. ${ }^{80}$ No matter how heartfelt it may be, an appeal to morality can at best motivate voluntary action. ${ }^{81}$ In this regard, we agree with the comments of Professor Ronald Silverman:

All too many proponents of mandatory pro bono seem to have overrelied on a powerful, but ultimately unsatisfying, moral rhetoric. Urgent and sincere calls to duty, however elegantly phrased and securely anchored ... to the best of our professional traditions, may be little more than empty and unpersuasive moral incantations.

Of course, there is also a more instrumental aspect to morality and good will. Perhaps a little morality might rescue lawyers from their current position at the nadir of public esteem. ${ }^{83}$ It has been suggested that one of the principal reasons for the constant outpouring of scorn is the bar's failure to make legal services broadly available. ${ }^{84}$ Certainly, there is a broad and visible gap between the "ceremonial rhetoric" 85 of public service and the reality of high fees and limited access. Rayman Solomon demonstrates persuasively that such discontinuity has been responsible for past crises in public perceptions of the legal profession.

Thus, it has been argued that attorneys should improve their im-

${ }^{80}$ See Brown, supra note 67, at 466 n.62; Eldred \& Schoenherr, supra note 65, at 393 (stating that "lawyers cannot be mandated to donate their labor... [P]ro bono must remain a matter of individual conscience, to be performed as an act of benevolence and charity, rather than as a matter of professional responsibility" (footnote omitted)).

${ }^{81}$ A person cannot be forced to exercise good will. Any attempt to do so should be rejected as paternalistic, or worse. See Mary Coombs, Your Money or Your Life: A Modest Proposal for Mandatory Pro Bono Services, 3 B.U. PUB. INT. L.J. 215, 226 (1993) ("[W]e ought not require adults to do something because we think it is good for them." (footnote omitted)).

82 Ronald H. Silverman, Conceiving a Lawyer's Legal Duty to the Poor, 19 HOFSTRA L. REV. 885, 912 (1991).

83 Is citation really necessary for this point? Heard any good lawyer jokes lately?

84 See Gary A. Hengstler, Vox Populi: The Public Perception of Lawyers, 79 ABA J. 60, 61 (1993) (discussing a survey that found $43 \%$ of the public believed that the provision of free services would improve the image of lawyers).

${ }_{86}^{85}$ Gordon, supra note 58, at 24 (footnote omitted).

See Solomon, supra note 11 , at $144-73$. 
age by implementing pro bono programs. ${ }^{87}$ We believe in pro bono work, and we believe that increased public service would enhance the reputation of lawyers. Nonetheless, mandatory pro bono plans are, by definition, enforced by the courts; lawyers who do not comply risk their licenses and livelihoods. It is not the job of the state to improve the public perception of the legal profession. Accordingly, image repair, no matter how desirable, cannot provide the rationale for the establishment of a compulsory pro bono obligation.

\section{THE "PUBLIC ASSETS" THEORY}

Our public assets theory rests on the proposition that lawyers are continually engaged in the sale of certain publicly created goods to their clients. This sale creates a quantum of profit, or rent, that is not attributable to the lawyers' human capital. A mandatory pro bono plan can recapture some portion of this profit and return it to the public as an in-kind assessment.

Some public resources, such as land and money, are tangible. Others are more conceptual-such as use of airwaves or access to information. We submit that certain prerogatives of lawyers and their clients should be classified as public assets. Specifically, the attorneyclient privilege (in its various forms), the work product doctrine, and certain conflict of interest rules are all publicly created resources, which we call "lawyer-commodities." These resources are made available to lawyers, who use them to the advantage of their clients, thus enhancing the value of their services. In each case, the lawyer and client receive a publicly created benefit which cannot be employed or enjoyed by nonlawyers. ${ }^{88}$

Although the conventional view is that lawyer-assets exist primarily for the benefit of clients, we will demonstrate that they also produce significant value both for the legal profession and for individual attorneys. For example, lawyers are able to sell the assurances of privacy embodied by both the ethical requirements of confidentiality and the evidentiary attorney-client privilege. ${ }^{89}$ The work product doc-

${ }^{87}$ See IN THE SPIRIT OF PUBLIC SERVICE, supra note 11, at 47-50 (discussing a need for increased pro bono service); Burke et al., supra note 4, at 62 (noting that pro bono activity could improve the public perception of lawyers).

${ }^{88}$ See Jaffee v. Redmond, 116 S. Ct. 1923, 1933 (1996) (Scalia, J., dissenting) (observing that no federal confidentiality privilege exists for tax advisors or accountants).

MOdel Rules of Professional CONDUCt Rule 1.6 (mandating that lawyers generally not "reveal information relating to representation of a client"); MODEL CODE 
trine allows lawyers to guarantee that others will not have access to the work undertaken on behalf of clients. ${ }^{90}$ The conflicts rules engender greater client confidence in lawyers, by preventing them from turning their abilities against clients in the future."

Ethics duties and evidentiary privileges are both created and enforced by the state. While some commentators see such provisions as merely filling gaps in attorney-client contracts, ${ }^{92}$ the reality is that ethics rules do more than simply lower the cost of negotiating private retention agreements between lawyers and their customers. Ethics rules are enforced by the disciplinary powers of each jurisdiction. They are supported by investigative staffs and special adjudicatory bodies. In other words, they represent the active intervention of state government to assure that clients receive the full value of special privileges such as confidentiality and loyalty. Moreover, each state also protects extraordinary rights of secrecy between lawyers and clients, not made available in other professional contexts. ${ }^{93}$

Clients pay fees in exchange for the use of these lawyer-assets; but fees are not the only costs. The invocation of privilege in litigation makes the discovery process more time consuming and expensivenot only to clients, but also to the publicly funded judicial system. ${ }^{94}$ Lawyers benefit doubly, first in the form of higher rates and again in the form of increased billable hours.

There has been considerable debate in recent years over the utility of the various confidentiality privileges. Some argue that attorneys are the sole ${ }^{95}$ or primary ${ }^{96}$ beneficiaries of the privileges. Others sup-

OF PROFESSIONAL RESPONSIBILITY DR 4-101 (requiring that lawyers generally preserve confidences and secrets of clients); FED. R. EVID. 501 (evidentiary privileges).

${ }_{90}$ See FED. R. CrV. P. 26(b) (3) (party may with hold otherwise discoverable evidence if it is prepared by or for counsel in anticipation of litigation); Hickman v. Taylor, 329 U.S. 495 (1947) (common law predecessor of Rule 26(b) (3)).

${ }^{91}$ See MODEL RULES OF PROFESSIONAL CONDUCT Rule 1.7 (regulating lawyers' representation of clients presenting potential conflicts of interest); see also Ronald Rotunda, Conflicts Problems When Representing Members of Corporate Families, 72 NOTRE DAME L. REV. 655 (1997).

${ }_{92}$ See Macey \& Miller, supra note 7, at 1107-08.

93 See Jaffee v. Redmond, 116 S. Ct. 1923, 1933 (1996) (Scalia, J., dissenting) (observing that no federal confidentiality privilege exists for tax advisors or accountants; in addition, state psychotherapist privileges have many exceptions and may not apply to all licensed professionals).

${ }^{94}$ See Ronald J. Allen et al., A Positive Theory of the Attorng-Client Privilege and the Work Product Doctrine, 19 J. LEGAL STUD. 359, 360 (1990) (explaining that costs imposed on discovery are necessary to encourage disclosure).

${ }^{95}$ See, e.g., Elizabeth Thornburg, Rethinking Work Product, 77 VA. L. REV. 1515, $1571-$ 72 (1991) (arguing that the work product doctrine encourages inefficient use of at- 
port the more traditional view that clients need and depend on the ability to repose confidences in their counsel. ${ }^{97}$ Under any conception of attorney-client privilege or work product doctrine, ${ }^{98}$ however, attorneys stand in a position to exploit the existence of lawyer-assets."

In the following Sections, we will discuss four distinct lawyerassets. The first two assets derive from principles of ethics-the duty of confidentiality and certain conflict of interest rules. The other two assets are drawn from the law of evidence-the attorney-client privilege and the work product doctrine. In each case, four conclusions seem evident: (1) the assets make lawyers' services more valuable to consumers, thus providing a direct monetary benefit to attorneys; (2) use of the assets imposes substantial costs on both the legal system and participants in the system; (3) lawyers are able to shift the costs created by the exploitation of these publicly created commodities; and (4) there is no current effort to recapture any of the rents that accrue to lawyers by virtue of their resale of public assets.

\section{A. Ethics Based Assets}

The rules of lawyers' ethics create two assets-confidentiality and loyalty-which lawyers then sell to clients. In the following Sections we will explain how the sale of these publicly created commodities serves to enhance lawyers' income.

\section{Confidentiality}

Rule 1.6 of the Model Rules of Professional Conduct provides that "a lawyer shall not reveal information relating to representation of a client unless the client consents after consultation." 100 Although there

torney time).

${ }^{96}$ See, e.g., Vincent C. Alexander, The Corporate Attomey-Client Privilege: A Study of the Participants, 63 ST. JOHN's L. REV. 191, 276-86 (1989) (arguing that corporate attorneyclient privilege may encourage retention of outside legal counsel).

${ }_{97}$ See Allen et al., supra note 94, at 361-62; Note, Attorney-Client and Work Product Protection in a Utilitarian World: An Argument for Recomparison, 108 HARV. L. REV. 1697, 1699 (1995) (noting that confidentiality "enables attorneys to provide the best possible legal advice" (footnote omitted)). II.A.2.

${ }_{98}$ The same conclusions apply as well to certain conflicts rules. See infra Part

${ }^{99}$ Our theory does not rest upon any particular normative conclusion concerning the desirability of any particular confidentiality rule. So long as the rules exist, whether optimal or not, they support our public commodities theory.

${ }^{100}$ MODEL RULES OF PROFEsSional CONDUCT Rule 1.6(a). The corresponding provision in the Model Code is found at MODEL CODE OF PROFESSIONAL RESPONSI- 
are exceptions to this confidentiality provision, ${ }^{101}$ its sweep is broad indeed. Lawyers are required to maintain the confidentiality not only of direct communications from their clients, but also of all information relating to representation, whether or not it originated with the client. ${ }^{102}$ Moreover, the ethical requirement of confidentiality applies to all representation of all clients, whether or not in litigation. The confidences of venture capitalists and ordinary taxpayers are protected in the same manner as those of personal injury plaintiffs and criminal defendants.

The operative rule, then, commands lawyers to hold in strict confidence all information conveyed by their clients and all other information they obtain or develop in the course of representation. The attorney may not divulge or disclose such information without the clients' explicit or implied consent, ${ }^{103}$ other than in certain narrowly defined circumstances. ${ }^{104}$ Additionally, the attorney may not use client information, even without disclosure, for the benefit of someone other than the client. ${ }^{105}$ Moreover, as we will develop in the next Section, the mere possession of client information, without actual disclosure or use, may nonetheless prohibit the lawyer from accepting future representation adverse to the client. ${ }^{106}$

BILITY DR 4-101 (1979). A version of one or the other provision has been adopted in every United States jurisdiction. See ABA/BNA LAWYERS' MANUAL ON Professional CONDUCT, supra note 14.

${ }^{101}$ See MODEL RULES OF PROFESSIONAL CONDUCT Rule 1.6(b); MODEL CODE OF PROFESSIONAL RESPONSIBILITY DR 4101(C).

${ }^{102}$ See Charles W. WOLFRAM, MODERN LEGAL ETHICS $\$ 6.7$ (practitioners' ed., 1986); MODEL RULES OF PROFESSIONAL CONDUCT Rule $1.6 \mathrm{cmt}$.; MODEL CODE OF PROFESSIONAL RESPONSIBILITY EC 5-4.

${ }^{103}$ See MODEL RULES OF PROFESSIONAL CONDUCT Rule 1.6(a) \& cmt.; MODEL CODE OF PROFESSIONAL RESPONSIBILITY DR 4-101(C) (1).

${ }^{104}$ See supra note 101 . One exception to the requirement of confidentiality occurs when the lawyer is ordered by a court to disclose information. The testimonial privilege, however, reduces greatly the likelihood of such an occurrence. See infra Part II.B.1.

${ }^{103}$ See Model Rules of Professional Conduct Rule 1.9(c); MOdel CODE OF PROFESSIONAL RESPONSIBILITY DR 4-101(B)(3); see also WOLFRAM, supra note 102, $\S \S 6.7 .6$ ("Lawyer Self Dealing in Client Information") \& 6.7.7 ("Authorized Use of Client Information").

${ }^{106}$ See MODEL RULES OF PROFEsSional CONDUCT Rules 1.7 ("Conflict of Interest: General Rule"), 1.8 ("Conflict of Interest: Prohibited Transactions"), \& 1.9 ("Conflict of Interest: Former Client"); MODEL CODE OF PROFESSIONAL RESPONSIBILITY DR 5-101 ("Refusing Employment When the Interests of the Lawyer May Impair His Independent Professional Judgment") \& DR 5-101 ("Refusing to Accept or Continue Employment if the Interests of Another Client May Impair the Independent Professional Judgment of the Lawyer"). 
These are provisions with some teeth. Lawyers may be subject to discipline for violating confidentiality rules. ${ }^{107}$ More frequently, lawyers have been disqualified from cases because of the confidences that they acquired from former clients. ${ }^{108}$ In both circumstances, lawyers stand to pay significant penalties for violating a client's trust.

Without the existence of lawyers' ethical duties, a client would undertake serious risk when sharing secret, valuable or sensitive information with her attorney. The lawyer might be tempted to appropriate the information to her own advantage, to sell it to the client's enemies or competitors, to use it against the client in future negotiations or litigation, or to be careless in keeping the information secure.

Even if the lawyer promised to maintain absolute secrecy, the client would still have to worry about cheating. In the absence of adverse consequences, a lawyer might consider cheating whenever the anticipated value of revealing a confidence was greater than the value of maintaining a relationship with the client. Without reassurance, clients would be less willing to engage lawyers and more reluctant to trust them with confidences once retained. ${ }^{109}$ Lawyers, in turn, would suffer lower fees, both by the hour and in toto, as invariably happens in the case of reduced demand.

The problem of trust, of course, exists in most professional or commercial relationships. It is generally thought that sellers overcome this dilemma through investment in reputation capital. ${ }^{110} \mathrm{~A}$

${ }^{107}$ See, e.g., Lawyer Disciplinary Bd. v. McGraw, 461 S.E.2d 850, 852 (W. Va. 1995) (reprimanding the Attorney General of West Virginia for violating client confidentiality); In re Lichtenberg, 871 P.2d 981 (N.M. 1994) (suspending lawyer for using prospective client's confidences to benefit another client).

${ }^{108}$ The origin of the disqualification doctrine lies in the need to protect client confidences, even after the conclusion of the representation. See Analytica, Inc. v. NPD Research, Inc. 708 F.2d 1263 (7th Cir. 1982); Cinema 5, Ltd. v. Cinerama, Inc., 528 F.2d 1384 (2d Cir. 1976); see also National Med. Enters. v. Godbey, 924 S.W.2d 123, 124-33 (Tex. 1996) (disqualifying law firm that had received confidences from former employees of corporation from lawsuit adverse to that corporation); In re Complex Asbestos Litig., 283 Cal. Rptr. 732, 740-48 (Ct. App. 1991) (disqualifying law firm because newly hired paralegal had been employed by opposing counsel and therefore possessed confidential information).

${ }^{109}$ This is not to say that lawyers would go out of business. Clients who absolutely needed lawyers would continue to consult them, even at the risk of disclosed confidences. Clients, however, would resort to their own calculus, conferring with counsel only when the expected value of the advice exceeded the possible loss from leaked information. Thus, to the extent that the potential for leakage can be reduced, the demand for consultation should increase.

${ }^{110}$ See generally Ronald J. Gilson, Value Creation by Business Lawyers: Legal Skills and 
cheating seller, in this case a lawyer who has developed a reputation for violating confidences, would eventually find herself without clients. Consequently, lawyers profit from investing in reputation capital, which allows them to attract and keep clients. A good reputation becomes, in effect, the lawyer's bond; better reputations allow lawyers to charge premium fees."

For our current purpose, the crucial observation here is that lawyers' incomes can be maximized through enhanced assurances of secret keeping. Reputation alone, however, can supply only a limited level of assurance. This is so for two reasons.

First, buyers of legal services can only verify lawyers' reputations by incurring high information or search costs. Even then, clients are not well equipped to evaluate information concerning lawyers, including those of apparently high rank, ${ }^{112}$ which should lead clients to mistrust the reliability of information. Also, the greatest quantity of reputation capital is characteristically accumulated by law firms; certainly the greatest expenditures on reputation capital are made by firms. ${ }^{113}$ On the other hand, clients actually share their confidences with individual members of those firms. Given sufficient economic incentive, a single lawyer might be tempted to betray a client if most of the cost of the betrayal (in the form of damaged reputation) could essentially be shifted to the firm.

This brings us to the second problem a client faces in relying on reputation as a bond for lawyers' performance. A bond is effective only so long as its value is greater than the profit available from cheating. ${ }^{114}$ Should the benefit of disclosing (or appropriating, or sharing,

Asset Pricing, 94 YALE L.J. 239 (1984); Benjamin Klein \& Keith B. Leffler, The Role of Market Forces in Assuring Contractual Performance, 89 J. POL. ECON. 615, 616 (1981); Karl S. Okamoto, Reputation and the Value of Lawyers, 74 OR. L. REV. 15, 22 (1995); Oliver L. Williamson, Credible Commitments: Using Hostages to Support Exchange, 73 AM. ECON. REV. 519 (1983).

11 See Okamoto, supra note 110, at 22-23.

112 See, e.g., Sara Fritz, Hubbell Admits to Fraudulently Billing Clients, L.A. TIMES, Dec. 7, 1994, at Al (describing how a former Associate United States Attorney General and partner at Rose Law Firm engaged in fraudulent overbilling); Howard Mintz, Flato's Free Fall, AM. LAW., Sept. 1996, at 60 (questioning why a former Latham \& Watkins partner embezzled hundreds of thousands of dollars from clients and firm); Randall Samborn, Complaint Puts Fraud at \$500K, NAT'L L.J., Sept. 19, 1994, at A4 (reporting that a former managing partner of Winston \& Strawn was charged with embezzling one half-million dollars).

113 See Marc Galanter \& THOMas PaLAY, TOURNAMENT OF LAWYERS: THE TRANSFORMATION OF THE BIG LAW FIRM 88-108 (1991) (explaining how large law firms tend to expand their human capital resources-including reputation-continuously).

${ }^{114}$ See Okamoto, supra note 110, at 22 ("[S]o long as the value of the firm-specific 
or diverting) a client's confidences ever outweigh the potential loss of reputation, ${ }^{115}$ then the lawyers' reputation-bond would be correspondingly devalued.

Reputation can provide a certain comfort level to clients, thus justifying premium fees to lawyers, but its ultimate value is uncertain and therefore self-limiting. Lawyers, however, are able to extend their clients greater assurances of confidentiality. In addition to the relatively insecure bond provided by reputation, lawyers may also guarantee consumers that the "ethics" of the legal profession ensure the inviolability of client confidences. Lawyers who breach client confidences not only trespass a moral code, but also disobey an enforceable legal code. ${ }^{116}$ Thus, a lawyer who cheats on a client risks not only reputation capital, but also her license to practice.

In essence, the lawyer's license operates as a performance bond. The client is assured of the sanctity of her secrets by virtue of the lawyer's interest in maintaining membership in the bar. Unlike reputation, licensure is relatively easy to verify (thus reducing the client's information costs) and has a high personal value to each lawyer (thus reducing the client's uncertainty). One might wonder whether ethics alone would provide a greater assurance to clients than reputation alone. But it is a moot question; lawyers offer both bonds. The inquiry is not whether the ethics-asset provides the most value, but only whether it provides added value.

While reputation capital is primarily self-generated, lawyers' ethics-assets are not. The value created by the ethics rules is given to lawyers, not accumulated by them. ${ }^{117}$ The duty of confidentiality is created by the state and enforced through publicly funded mechanisms

investment, that is, the income stream generated by the reputation for quality, exceeds the profit obtainable from a single incident of cheating, the firm will not cheat.").

${ }^{15}$ Consider the actions of attorney Michael Khourie. Mr. Khourie, while representing the plaintiffs in a nationwide class action, secretly approached an attorney for the defendant corporation and offered to "abandon and dismiss" the class action in exchange for a confidential payment of " $\$ 8$ to $\$ 10$ million to him personally; the class would receive nothing." Cal Pak Delivery, Inc. v. United Parcel Serv., 60 Cal. Rptr. 2d 207, 210 (Ct. App. 1997).

${ }^{116}$ For example, in the case of Michael Khourie, see supra note 115, the California appellate court imposed sanctions that went well beyond loss of reputation. As a consequence of Mr. Khourie's offer to "sell out" his clients, the court disqualified him from all participation in the litigation and limited his right to seek attorney's fees. Cal Pak Delivery, Inc., 60 Cal. Rptr. 2d at 214-16. Mr. Khourie's actions would also seem to make him a prime candidate for professional discipline. As of this writing, however, it is not known what actions the California bar counsel may take against Mr. Khourie.

${ }_{117}$ The fee premium attributable to reputation capital is a return on investment; the fee premium attributable to ethics-assets comes in the form of a rent or quasi-rent. 
of investigation and discipline. ${ }^{118}$ These publicly supported infrastructures serve to further reduce clients' information and enforcement costs, which might otherwise discount the fee premium available to lawyers. Lawyers, therefore, are able to offer the ultimate performance bond as a guarantee of confidentiality-the lawyer offers her license as a hostage, with the state acting as the stakeholder.

Most commentators would agree that the confidentiality rules are intended to protect clients and serve social ends, ${ }^{119}$ not to increase lawyers' fees. Nonetheless, the confidentiality rules have the effect of contributing to lawyers' incomes. That this consequence is largely unintended only strengthens the argument in favor of recapturing some of those earnings for public use.

\section{Conflicts of Interest}

Conflict of interest rules are closely related to the confidentiality principle. The Model Rules of Professional Conduct contain several provisions delineating lawyers' responsibilities in this regard. ${ }^{120}$ Rule 1.7 contains the general principle that a lawyer may not represent a client if the representation will be directly adverse to another client, or if the representation may be materially limited by the lawyer's own interests or by responsibilities to another client or a third person. ${ }^{121}$ Rule 1.8 prohibits lawyers from engaging in certain transactions with clients, sets strict standards for entering business relationships with clients, and bars lawyers from using client confidences "to the disadvantage of the client." ${ }^{122}$ Rule 1.9 prohibits a lawyer from acting adversely to a former client in the "same or a substantially related matter." ${ }^{\text {123 }}$ Finally, Rule 1.10 imputes a lawyer's disqualification to her entire law firm. ${ }^{124}$

${ }^{118}$ See WOLFRAM, supra note 102 , at $82-85$ (detailing state disciplinary agencies and structures). ple").

${ }^{119}$ See, e.g., id. at $297-99$ (discussing the evolution of the "confidentiality princi-

The prior Model Code of Professional Responsibility contained provisions substantially similar to most of the requirements now found in the Model Rules. In a few cases, such as suing former clients, the Model Code was silent, but case law decided under the Model Code reached essentially the same result as was subsequently codified in the Model Rules. See MODEL CODE OF PROFESSIONAL RESPONSIBILITY Canon 5 Notes (1983), and cases cited therein.

121 MODEL RULES OF PROFESSIONAL CONDUCT Rule 1.7 (1983).

${ }^{122}$ Id. at Rule 1.8 .

123 Id. at Rule 1.9.

${ }^{124} I d$. at Rule 1.10. 
Taken together, these rules protect a client's ability to rely upon the loyalty of her counsel. A client may confide in her lawyer all manner of confidences, strategies, plans, vulnerabilities and aspirations, secure in the knowledge that the lawyer's access to this information will not come back to haunt her. Rule 1.7(a), for example, assures the client that her lawyer will not bring even an unrelated action against her during the course of the representation. ${ }^{125}$ In the same vein, Rule 1.9 prevents lawyers from switching sides, even after being discharged."

These are valuable assets. They protect clients' expectations and allow them to make greater use of attorneys. Some clients, of course, have no choice but to consult and trust counsel. A criminal defendant virtually has to have a lawyer, and the absence of conflicts rules would be unlikely to increase the incidence of pro se defense. But the need of other clients, including many of the most lucrative, is more contingent. Corporate and other business transaction clients would retain fewer attorneys (or would retain them less extensively) if they could not be certain of their lawyers' loyalty. ${ }^{127}$

As with confidentiality in general, reputation capital can also perform a bonding function. A lawyer or law firm that developed a reputation for switching sides would quickly face a diminishing client base. Nonetheless, without a regime of enforcement, the economic benefit of switching sides might, in some cases, overwhelm the cost in lost reputation.

The ethics rules, however, absolutely prevent lawyers from switching sides, rather than merely penalizing them for doing so (in the

${ }^{125}$ The client may consent to the lawyer undertaking such adverse representation, but only following consultation and full disclosure. Id. at Rule 1.7(a)(2).

${ }^{126}$ Again, the client can consent. Id. at Rule 1.9(a).

${ }^{127}$ Professor Fred C. Zacharias suggests to the contrary that most lawyers "would argue that conflicts rules ... hurt their business." Letter from Fred Zacharias, Herzog Scholar and Professor of Law, University of San Diego School of Law, to Steven Lubet, Professor of Law, Northwestern University School of Law 3 (Aug. 19, 1996) (on file with authors). Professor Timothy Terrell makes the same point: "Practicing lawyers understand themselves to be constrained by conflicts rules ...." Letter from Timothy Terrell, Professor of Law, Emory University School of Law, to Steven Lubet 5 (Aug. 20, 1996) (on file with authors).

We agree that many attorneys may hold that view, but the perception cannot be accurate. The disqualification of one lawyer requires the employment of another. Thus, the total volume of legal business cannot be hurt by the conflicts rules, and it almost certainly goes up somewhat due to the necessary duplication of effort. Of course, the bitter experience of being booted out of a case or transaction is no doubt more memorable than the client who was referred due to another lawyer's conflict. 
form of reputation cost). The development of the disqualification motion or petition makes it certain that one's lawyer cannot be hired away by an opponent or direct competitor, and cannot even defect after being fired. ${ }^{128}$ The client does not need to contract for this protection, and does not need to indulge in costly information searches. Imagine the negotiation that might occur in the absence of a conflicts rule:

CLIENT: I would like to hire you, but only if I can be certain you will never take on representation adverse to me, in this or in any related matter.

COUNSEL: Don't worry. I promise not to do it.

CLIENT: How can I be sure?

COUNSEL: I will lose reputation capital if I switch sides. My reputation is my bond.

CLIENT: That is not a very good bond. What if my case turns out to be more valuable than your reputation? If you can't provide a better bond, I will insist on discounting your fee to account for your uncertain loyalty.

The ethics rules, however, allow the lawyer to provide the client with a nearly ironclad assurance. "I cannot switch sides. Not only would that endanger my license, but the court will throw me out of the case if I try."

The provisions of Rules 1.7 and 1.9 seem to focus on litigation clients, but in reality they are not so limited. Business clients are guaranteed that their lawyers will act with fidelity, and will not organize transactions with others' interests in mind. They are also protected against being sued (by their own attorneys or their firms) in the future, should a deal go bad. Moreover, Rule 1.8 gives additional assurances to strictly transactional clients: their lawyers cannot appropriate the benefits of the deal, and cannot structure legal arrange-

${ }^{128}$ See, e.g., Cardona v. General Motors Corp., 942 F. Supp. 968, 975 (D.N.J. 1996) (side-switching attorney must be disqualified in order to protect client who "freely shared with the attorney secrets and confidences with the expectation that they would be disclosed to no one else").

${ }^{129}$ To be sure, some disqualification motions are more marginal than others. Sometimes lawyers are disqualified by courts, sometimes the motions fail. The reported cases, however, only recount the situations where lawyers attempted to sue their current or former clients; by definition, those would be the cases where the disqualification rules were least likely to apply. The reported cases obviously do not capture the overwhelming majority of instances where lawyers were effectively deterred from even trying to change sides. 
ments to serve themselves at the expense of their clients. ${ }^{130}$

Each of these protections is publicly created and publicly enforced. Each adds to the value of lawyers' services by making them more desirable and dependable. As with pure confidentiality, attorneys are able to sell conflicts-assets. ${ }^{131}$

\section{B. Evidence-Based Assets}

The ethics principle of confidentiality serves to restrain lawyers' voluntary actions. It is therefore arguable that an attorney's interest in preserving reputation capital will also restrain counsel, thereby fulfilling some of the same functions as the confidentiality rules. From the client's perspective, however, there remains the potential problem of compelled disclosure via discovery or subpoenaed testimony. In this regard, reputation capital is worthless. If ordered by a court to reveal client secrets, the lawyer is helpless and must obey whatever the cost to her reputation. To the extent that communications to counsel are vulnerable to such exposure, the value of a lawyer's services is diminished.

Once again, however, lawyers' incomes are fortified by virtue of their access to publicly created commodities. In addition to ethicsassets, attorneys are empowered to sell to their clients certain evidence-based protections. Both the evidentiary attorney-client privilege and the closely connected work product doctrine allow lawyers to offer further guarantees of secrecy to their clients, even in the face of demands from adversaries or courts. These protections come at no cost to lawyers, and pose no risk to reputation capital, yet they impose substantial costs on third parties. The ability to shift those costs, of course, contributes further value to lawyers' services, which may be realized in the form of fees.

\section{Attorney-Client Privilege}

The attorney-client privilege is the rule of evidence that permits a lawyer to refuse to testify in court concerning communications between herself and her client. The privilege is considerably narrower

190 See MODEl RULES OF PROFESSIONAL CONDUCT Rule 1.8(a) (1983) (governing business transactions with clients); Rule 1.8(b) (prohibiting use of confidential information to disadvantage of client); Rule 1.8(c) (limiting gifts or bequests from clients to lawyers and their families); Rule 1.8(d) (prohibiting acquisition of literary rights before conclusion of representation).

${ }^{191}$ For an argument to the contrary, see supra note 127. 
in scope than the ethical principle of confidentiality, since it applies only to "communications" (and not to other information relating to the representation). ${ }^{132}$ On the other hand, the privilege may be more sturdy than the ethical principle, since it protects the client not only from the lawyer's voluntary (or negligent) lapses, but also from compelled disclosure in court. ${ }^{133}$ The privilege, though obviously germane only once litigation is pending, ${ }^{134}$ applies to all confidences shared between clients and their lawyers, including those that take place in the context of transactional practice and business counseling. Communications do not need to be in contemplation of litigation in order to be protected, ${ }^{135}$ and the privilege continues to apply even after the death of the client. ${ }^{196}$

Every United States jurisdiction has adopted some version of the attorney-client privilege. ${ }^{137}$ In the federal cases, the privilege exists by virtue of Rule 501 of the Federal Rules of Evidence. ${ }^{138}$ The history of the attorney-client privilege, of course, is far older than the federal rules;

192 See MODEL RULES OF PROFESSIONAL CONDUCT Rule $1.6 \mathrm{cmt}$. (1983) (stating that the requirement of confidentiality extends to situations beyond those where evidence is being sought); WOLFRAM, supra note $102, \S 6.7$ (comparing evidentiary rule with ethics requirement of confidentiality); 24 CHARLES ALAN WRIGHT \& KENNETH W. GRAHAM, JR., FEDERAL PRACTICE AND PROCEDURE, EVIDENCE \$ 5472, at 89-90 (1986) (stating that the attorney-client privilege "is concerned with the question of when courts can compel the disclosure of confidential communications between attorney and client; the duty of confidentiality imposes an obligation on the attorney to keep his client's confidences, whether in or out of court").

${ }^{193}$ See, e.g., United States v. Rowe, 96 F.3d 1294, 1297 (9th Cir. 1996) (holding that fact-finding done by attorneys comes within the attorney-client privilege); Hitt v. Stephens, 675 N.E.2d 275, 278-79 (Ill. App. Ct. 1997) (holding that the will-contest exception to the attorney-client privilege does not apply to files used by the defendant in representing a client's estate which has been closed).

${ }^{134}$ Although it is most frequently utilized in the course of litigation, the privilege may also be invoked in other dispute-resolution contexts such as arbitration, tax audits, regulatory compliance and mediation.

${ }^{135}$ See, e.g., Hitt, 675 N.E.2d at 278 (noting that statements made in the course of estate planning are held privileged even many years after the death of the client).

${ }^{156}$ See id.

${ }^{137}$ See WOLFRAM, supra note $102, \S 6.3 .1$, at 250.

138 "[T] $[$ he privilege of a witness... shall be governed by the principles of the common law as they may be interpreted by the courts of the United States in the light of reason and experience." FED. R. EVID. 501. Federal courts may apply state law privilege doctrines in diversity cases. See generally 2 J. WEINSTEIN \& M. BERGER, WEINSTEIN'S EVIDENCE I 501[02]. Until 1996, the attorney-client privilege was the only common law privilege recognized by the United States Supreme Court, and therefore applicable in federal cases, pursuant to Rule 501. On February 26, 1996, the Court decided Jaffee v. Redmond, 116 S. Ct. 1923 (1996), which, for the first time, accepted under Rule 501 a claim of psychotherapist privilege. See id. at 1931. 
it was first recognized by the United States Supreme Court in Hunt $v$. Blackburn in 1888, when the Court held that the privilege was "founded upon the necessity, in the interest and administration of justice, of the aid of persons having knowledge of the law and skilled in its practice, which assistance can only be safely and readily availed of when free from the consequences or the apprehension of disclosure." ${ }^{139}$

Since Hunt $v$. Blackburn, the existence of the attorney-client evidentiary privilege has hardly been debated in the courts. ${ }^{140}$ Subsequent cases have, however, focused on the scope of the privilege. Upjohn Co. v. United States, for example, extended the privilege to corporations. $^{141}$

The most common rationale for the privilege is that it encourages candid communications between lawyer and client, ${ }^{142}$ including unfavorable information that the client might otherwise withhold. ${ }^{143}$ Professor Ronald Allen and his coauthors posit that the attorney-client privilege has the effect of increasing the opposition's cost of acquiring information, and that it therefore encourages clients to share unfavorable information with counsel. ${ }^{144}$ Client candor, in turn, is said to lead to better representation, ${ }^{145}$ as well as to counsel's increased ability to encourage compliance with the law. ${ }^{146}$

Other scholars are critical of the "candor" rationale. Some argue

${ }^{199}$ Hunt v. Blackburn, 128 U.S. 464, 470 (1888).

${ }^{140}$ Scholars, however, have questioned its need or utility. See infra text accompanying notes $147-48$.

${ }^{141} 449$ U.S. 383,397 (1981) (holding that communications made by a litigant's employees are covered by the attorney-client privilege to the extent that they are answers to questionnaires or interview questions).

${ }^{142}$ See id. at 389 (stating that the privilege facilitates "full and frank communication between attorneys and their clients").

${ }^{143}$ See MONROE H. FREEdMAN, LAWYERS' ETHICS IN AN ADVERSARY SYSTEM 4 (1975) (agreeing with the theory that, in order to effectively represent a client, an attorney must know all that her client knows); MONROE H. FREEDMAN, UNDERSTANDING LAWYERS' ETHICS 87-109 (1990) (discussing privilege in a chapter entitled, "LawyerClient Trust and Confidence"); Note, supra note 97, at 1699 (asserting that a lawyer's ability to give the best possible advice depends on client openness).

144 See Allen et al., supra note 94 , at 369.

145 See Upjohn, 449 U.S. at 389; 24 WRIGHT \& GRAHAM, supra note 132, §5472, at 8082. See generally Monroe H. Freedman, Are the Model Rules Constitutional?, 35 U. MIAMI L. REV. 685 (1981).

${ }^{146}$ See Vincent C. Alexander, The Corporate Attorney-Client Privilege: A Study of the Participants, 63 ST. JOHN'S L. REV. 191, 213-14 (1989) (“[D] eprived of complete information, the attorney cannot give the most competent legal advice, and the administration of justice will suffer either because of the perpetuation of meritless litigation or noncompliance with the law."). 
that clients have a deep and apparent interest in providing truthful information to their attorneys, whether the communications are privileged or not. ${ }^{147}$ If so, the privilege would have little or no effect on the actual quality of representation. ${ }^{148}$

The resolution of this debate is not necessary to our theory. Whether or not the attorney-client privilege is essential to competent representation, it is apparent that the privilege is highly valued by both lawyers and their customers. In one survey, forty-five percent of lawyers and thirty-one percent of business executives responded that the attorney-client privilege "increases the frequency of consultation." ${ }^{149}$ A majority of both lawyers and executives believed that the privilege encourages candor, ${ }^{150}$ and many also suggested that it fosters an atmosphere of client comfort. ${ }^{151}$ Another survey suggested that the privilege promotes the perception of lawyers as "hired guns." ${ }^{\text {"152 }}$ While this image is distasteful to some, it is obviously desirable to clients in search of gunslingers. Thus, Professor Fred Zacharias has observed that "the presence of confidentiality may explain why clients are willing to pay high fees to lawyers when non-lawyers might be able to provide similar services more cheaply." ${ }^{153}$

Indeed, the attorney-client privilege may have greater value to clients if it is unnecessary or even socially undesirable. Assuming arguendo that frank communication would nonetheless take place between lawyers and clients without the privilege, it should be obvious that clients would prefer that their bad facts be kept secret. Can there be any doubt that secrecy, especially concerning potentially compromising information, is valuable and sought after? Perhaps it is for this reason that lawyers frequently admit to making "tactical use" of the privilege, employing it after-the-fact to thwart discovery rather than to promote candor in the first instance. ${ }^{154}$ Call it zeal or call it obstruc-

147 See Elizabeth G. Thornburg, Sanctifying Secrecy: The Mythology of the Corporate Attormey-Client Privilege, 69 NOTRE DAME L. REV. 157, 17479 (1993) (discussing other incentives for client candor); Fred C. Zacharias, Rethinking Confidentiality, 74 IOWA L. REV. 351, 367-69 (1989) (asserting that a feeling of confidentiality alone is not justification for the privilege).

${ }^{148}$ See Alexander, supra note 146, at 375; Thornburg, supra note 147, at 179-82;

Zacharias, supra note 147, at 366-67.

${ }_{139}$ See Alexander, supra note 146, at 248.

${ }^{130}$ See id, at 244.

151 See id.

152 See Zacharias, supra note 147 , at 360 .

153 Id.

${ }^{154}$ See Alexander, supra note 146, at 243-44. 
tionism, it is clearly an attractive commodity. It may be that wise social policy does not truly require an attorney-client privilege; all the more reason for clients to want its protection and to be willing to pay for it. ${ }^{155}$

\section{Work Product Doctrine}

Additionally, some lawyers sell clients the protection of the work product doctrine. ${ }^{156}$ While the attorney-client privilege shields the client's confidential communications, the work product doctrine applies to the lawyer's thoughts and conclusions. Thus, lawyers may resist production in discovery (and therefore the evidentiary use) of "documents and tangible things ... prepared in anticipation of litigation," 157 as a means of safeguarding the client's exclusive access to her lawyer's mental processes and opinions. ${ }^{158}$ The work product doctrine is thought to foster and promote attorney diligence, ${ }^{159}$ which obviously should be of great value to clients. Because work product protection applies only to material developed in the course of litigation, its scope is far more narrow than that of the attorney-client privilege, which applies to all confidential communications whatever their context. Transactional lawyers, for example, may never have occasion to invoke the work product doctrine. Still, the doctrine affords significant, and therefore valuable, shelter to those who are able to employ it.

First announced by the United States Supreme Court in Hickman v. Taylor, ${ }^{160}$ the work product doctrine has since been included in the Federal Rules of Civil Procedure ${ }^{161}$ and accepted by every state. In the

${ }^{155}$ See, e.g., United States v. Rowe, 96 F.3d 1294, 1297 (9th Cir. 1996) (holding that attorney-client privilege prevails despite academic criticism of its effect).

${ }^{156}$ The work product protection is variously described as a qualified immunity or a privilege. See generally Kathleen Waits, Opinion Work Product: A Critical Analysis of Current Law and a New Analytical Framework, 73 OR. L. REV. 385, 391-94 (1994). The difference between the two descriptions, if there is one, is not germane to our theory. Lawyers resell the protection of the doctrine, no matter how it is best classified analytically. Solely for the sake of consistency, we tend to use the term "privilege."

${ }_{157}^{15}$ FED. R.CIV. P. 26(b) (3).

${ }^{158}$ See United States v. Nobles, 422 U.S. 225, 238 (1975) ("At its core, the workproduct doctrine shelters the mental processes of the attorney, providing a privileged area within which he can analyze and prepare his client's case."); Hickman v. Taylor, 329 U.S. 495, 511 (1947) ("[I]t is essential that a lawyer work with a certain degree of privacy, free from unnecessary intrusion by opposing parties and their counsel.").

\footnotetext{
See Alexander, supra note 146, at 214-15.

160329 U.S. 495, 510-12 (1947).

161 FED. R. Crv. P. 26(b) (3).
} 
years since Hickman the work product privilege has expanded to cover documents prepared for attorneys by their agents, ${ }^{162}$ and resistance to subpoenas as well as to formal discovery. ${ }^{163}$ In addition, "carry over immunity" permits lawyers to assert work product protection even after the conclusion of the litigation for which the documents were prepared. ${ }^{164}$ Still, the work product doctrine must be regarded as the least valuable of the lawyer-assets under discussion. This is because, unlike the attorney-client privilege, the work product doctrine remains restricted to documents and information produced in "anticipation of litigation," and therefore its benefits are limited to relatively few lawyers and their clients.

Various rationales have been proffered in support of the work product privilege. In Hickman, the Supreme Court expressed the concern that absent such privilege, "[a]n attorney's thoughts, heretofore inviolate, would not be his own. Inefficiency, unfairness and sharp practices would inevitably develop in the giving of legal advice and in the preparation of cases for trial.... And the interests of the clients and the cause of justice would be poorly served." 165

Thoughtfully expanding upon this analysis, Professor Allen and his coauthors concluded that the work product rule is necessary to enable an attorney to undertake the "optimal amount of legal investigation." Since investigation and research typically produce both good and bad information, a lawyer otherwise might be reluctant to explore all avenues for fear of having to share any damaging results with the opposition. ${ }^{167}$

The work product privilege may also be seen as akin to a property right in information: An evidentiary privilege is a right to withhold information unless the adversary makes a concession (pays a price) worth enough to induce the privilege holder to waive (sell) his rights. The privilege is thus a species of property right in information. And it is a right against the world. ${ }^{168}$

${ }^{162}$ See Nobles, 422 U.S. at 238-39 ("It is therefore necessary that the doctrine protect material prepared for the attorney as well as those prepared by the attorney himself.").

${ }^{163}$ See Upjohn v. United States, 449 U.S. 383, 398 (1981) (holding that the work product doctrine applies to IRS summonses).

${ }^{164}$ D. Christopher Wells, The Attorney Work Product Doctrine and Camy-Over Immunity: An Assessment of Their Justifications, 47 U. PITT. L. REV. 675, 679-81 (1986).

${ }_{165}$ Hickman, 329 U.S. at 511.

${ }^{166}$ Allen et al., supra note 94 , at 362.

${ }^{167}$ See id. at 386-87.

${ }^{168}$ See Frank H. Easterbrook, Insider Trading, Secret Agents, Evidentiary Privileges, and the Production of Information, 1981 SUP. CT. REV. 309, 313-314; see also Morrow v. Brown, 
Under either conception, the work product doctrine plainly advantages lawyers' clients by allowing the suppression of otherwise relevant information. ${ }^{169}$ At a minimum, this capability, conferred via publicly created legal doctrine, increases the value of lawyers' efforts by broadening the scope of risk-free research and investigation. When the work product privilege is viewed as a property right, it becomes even more apparent that lawyers have been granted access to a wealth-producing public asset, which they proceed to barter and sell on behalf of both their clients and themselves. ${ }^{170}$

Critics of the work product doctrine dispute its necessity and social utility, arguing that lawyers have a strong incentive to prepare adequately and diligently even if the product of their labors might eventually be discoverable by an adversary. ${ }^{171}$ Thus, they contend that the work product privilege does not lead to more extensive investigation (that is, the production of case-specific knowledge), but only to justice-defeating suppression of the information gained. ${ }^{172}$

A superfluous benefit, however, is a benefit nonetheless. Lawyers and clients are assertively eager to utilize the advantages of the work product doctrine, ${ }^{173}$ all the more so because the asset is provided free

Todd \& Heyburn, $1996 \mathrm{Ky}$. App. LEXIS 173, at *8-9 (Ky. Ct. App. Nov. 11, 1996) (holding that law firm has an independent right to assert work product protection on its own behalf, notwithstanding client's waiver); RICHARD POSNER, THE ECONOMICS OF JUSTICE 244 (1981) ("[T]he attorney-work product-doctrine is, I think, best understood as the use of secrecy to protect the lawyer's (and hence the client's) investment in research and analysis of a case.").

${ }^{169}$ The lawyer, however, cannot invoke work product protection against her own client with regard to material amassed in the course of representing that client. See Clark v. Milam, 847 F. Supp. 424, 427 (S.D. W. Va. 1994); Gottlieb v. Wiles, 143 F.R.D. 241, 247 (D. Colo. 1992); Martin v. Valley Nat'l Bank of Ariz., 140 F.R.D. 291, 320 (S.D.N.Y. 1991). This exception, of course, makes the work product rule, and hence the lawyer's services, even more valuable to the client.

170 See Morrow, $1996 \mathrm{Ky}$. App. LEXIS 173, at *9 (holding that law firm has independent right to assert work product protection on its own behalf, notwithstanding client's waiver).

171 See Elizabeth Thornburg, supra note 147; D. Christopher Wells, The Attorney Work Product Doctrine and Carry-Over Immunity: An Assessment of Their Justifications, $47 \mathrm{U}$. PITT. L. REV. 675, 687 (1986); cf. In re Special Sept. 1978 Grand Jury (II), 640 F.2d 49, 62 (7th Cir. 1980) (work product doctrine provides "a protected area in which the lawyer can prepare his case free from adversarial scrutiny"); Morrow, 1996 Ky. App. LEXIS 173 , at $* 9$ (work product doctrine protects "thought processes of the attorney in evaluating and litigating a claim from being subsequently obtained and used against him or her").

172 See Wells, supra note 171, at 685 ("The goals of justice are not merely to provide incentives for the adversary system.").

${ }^{173}$ See, e.g., Morrow, $1996 \mathrm{Ky}$. Ct. App. LEXIS 173, at *8-9; THOMAS MaUET, PRETRIAL 178 (1993) (attorneys should include lawyer observations and opinions 
of charge, courtesy of the public. This does not mean, however, that there are no associated costs. The following Section addresses the "price" of both the attorney-client and work product privileges.

\section{Costs of Evidentiary Privileges}

Attorneys have been successful both at appropriating the benefits and shifting the costs of evidentiary privileges. There would be a significant negative impact on attorneys' incomes if the direct costs of the evidentiary privileges were borne by lawyers. In addition, if the costs of the privileges were fully passed through to clients who employed their protections, lawyers would necessarily suffer either decreased employment or reduced fees. As it is, however, the primary financial burdens generated by the evidentiary privileges are spread across the entire judicial system.

\section{a. Suppression of Truth}

It should come as no surprise that evidentiary privileges result in the suppression of truth. ${ }^{174}$ That is their intended function. Proponents of privileges typically argue that the trade-off between access to truth and respect for privacy is reasonable, necessary and fair. ${ }^{175}$ Critics, however, contend that recognized privileges are overbroad and can lead to injustice. ${ }^{176}$

A frequent pro-privilege argument is that recognition of a privilege is virtually cost-free, since the protected communications would not occur if unprivileged. The Supreme Court explained this premise in Upjohn: "Application of the attorney-client privilege to communications ... puts the adversary in no worse position than if the communications had never taken place. The privilege only protects

throughout summaries of witness statements, so as to gain work product protection from disclosure); DAN WEBB ET AL., CORPORATE INTERNAL INVESTIGATIONS § 4.05[2] (1993) (lawyers' written notes should weave together facts and mental impressions, so as to be nondiscoverable under work product doctrine).

${ }^{174}$ See, e.g., Jaffee v. Redmond, 116 S. Ct. 1923, 1933 (1996) (Scalia, J., dissenting) (noting that "[t]estimonial privileges... 'are in derogation of the search for truth" (quoting United States v. Nixon, 418 U.S. 683, 710 (1974))).

${ }_{173}$ See, e.g., Allen et al., supra note 94 , at 360 (recognizing that "the rules of confidentiality are costly" and that they "constrain openness," but arguing that these costs "are not regrettable" because confidentiality encourages client disclosure to her attorney who may "guide the litigation in directions unanticipated by the client").

${ }^{176}$ See, e.g., Thornburg, supra note 147 , at 159 (“[T] he privilege actually does great harm to the truth seeking function of litigation and imposes tremendous costs on the litigants and on the judicial system as a whole.") 
disclosure of communications; it does not protect disclosure of the underlying facts by those who communicated with the attorney "177

The Court recently reiterated this belief in Jaffee $v$. Redmond: "Without a privilege, much of the desirable evidence to which litigants ... seek access-for example, admissions against interest by a party-is unlikely to come into being. This unspoken 'evidence' will therefore serve no greater truth-seeking function than if it had been spoken and privileged."

The assumption of cost-free privileges, however, has been sharply criticized. Clients, both in and out of litigation, have enormous incentives to make full disclosure to their attorneys, even in the absence of an evidentiary privilege. As Professor Allen and his coauthors observed, "one of the effects of the privilege must be to raise the cost of obtaining useful information once it is in the hands of the attorney." 179

There is no empirical support for the proposition that clients would routinely withhold communications with counsel rather than risk discovery. On the other hand, Justice Scalia's dissent in Jaffee makes an almost incontrovertible case that much communication between clients and professionals is indifferent to privilege. Responding to the majority's position that truthful communication is inhibited by the absence of evidentiary protection, Justice Scalia queried: "If that is so, how come psychotherapy got to be a thriving practice before the 'psychotherapist privilege' was invented? Were the patients paying money to lie to their analysts all those years?"180

Indeed. Corporations routinely channeled information to their attorneys long before the Court recognized a corporate privilege. ${ }^{181}$ Lawyers gathered information via intermediaries before those communications were reliably privileged. ${ }^{182}$ Can there be any doubt that attorneys assiduously assembled work product well in advance of

\footnotetext{
177 Upjohn Co. v. United States, 449 U.S. 383, 395 (1981).

178 Jaffee, 116 S. Ct. at 1929.

179 Allen et al., supra note 94 , at 361.

${ }_{181}^{180}$ Jaffee, 116 S. Ct. at 1935 (Scalia, J., dissenting).

181 See Upjohn, 449 U.S, at $394-95$ (extending the attorney-client privilege to communications from corporate employees to the counsel for the corporation).

${ }^{182}$ See U.S. v. Koval, 296 F.2d 918 (2d Cir. 1961) (interpreter); Pratt v. State, 39 Md. App. 442 (1978) (psychiatrist); $c f$. Fisher v. United States, 425 U.S. 391, 405, 414 (1976) (holding that an accountant's documents transferred by client to attorney are not entitled to attorney-client privilege as the documents involved no selfincriminating testimony).
} 
Hickman $v$. Taylor? ${ }^{183}$ To this day it seems fairly safe to assume that clients are reasonably candid with their accountants, tax advisors, private investigators, business counselors, real estate brokers and estate planners, notwithstanding the absence of an evidentiary privilege that thoroughly covers those law-related professions. ${ }^{184}$

In short, the evidentiary privileges exact a price in the form of information suppression. Lawyers would hardly fight so hard for them if it were otherwise. The suppression of information, in turn, may result in the frustration of justice. "That is the cost of every rule which excludes reliable and probative evidence-or at least every one categorical enough to achieve its announced policy objective." 185

We do not presume here to resolve the policy disputes over the attorney-client privilege and the work product doctrine. Perhaps the gain in candid counseling is worth the lost information, perhaps not. It is sufficient for our purpose to recognize that evidentiary privileges impose a significant and diffuse social cost, and that lawyers pay no direct share of the price as they commandeer their benefits.

\section{b. Increased Litigation Costs}

A further cost of evidentiary privileges comes in the form of increased litigation expenses. Professor Allen and his coauthors have established fairly conclusively that evidentiary privileges multiply litigation and discovery expenses. As evidence, they point to the existence of numerous reported cases dealing with work product and attorney-client privilege issues. ${ }^{186}$ If the information sought in those cases could have been acquired easily or inexpensively through other means, the requesting parties obviously would not have resorted to litigation. ${ }^{187}$ Increased litigation, of course, is a boon to working lawyers, as it generates additional billable hours. ${ }^{188}$ Clients pay for those

183329 U.S. 495 (1947). For a discussion of the work product doctrine, see supra Part II.B.2.

${ }^{184}$ See, e.g., Jaffee, $116 \mathrm{~S}$. Ct. at 1935 (Scalia, J., dissenting) (suggesting that patients would not pay "money to lie to their analysts all those years" before the existence of a federal psychotherapist-patient privilege).

${ }_{185}$ Id. at 1932 (Scalia, J., dissenting).

${ }^{186}$ See Allen et al., supra note 94 , at 363 .

187 See id.

188 See Nancy D. Holt, Are Longer Hours Here to Stay?, 79 A.B.A. J., Feb. 1993, at 62, 64 (noting that a $1990 \mathrm{ABA}$ survey reveals that $50 \%$ of lawyers work more than 200 hours per month); Judith L. Maute, Balanced Lives in a Stressful Profession: An Impossible Dream?, 21 CAP. U. L. REV. 797, 802, 805 (1992) (noticing "the usual pressure for more business and billings" and that "some firms expect as much as twenty-five hundred bil- 
hours, and public taxes pay for the courts' time and support personnel.

The work product privilege additionally results in duplication of investigation. While the sharing of all relevant material might be more efficient for all concerned, the work product doctrine allows lawyers to withhold their own knowledge. Thus, each side neatly generates further billings for opposing counsel. ${ }^{189}$

Finally, evidentiary privileges impose even greater discovery costs in the corporate context. Under the Upjohn holding, opposing counsel may now be required to take the depositions of many employees who otherwise might simply have been interviewed. ${ }^{190}$ Depositions are expensive for clients, but they are lucrative for lawyers. ${ }^{191}$

\section{c. Work Shifting to High-Priced Providers}

One expensive effect of attorneys' unique access to secrecy is the shifting of work from low-price to high-price providers. There is often considerable overlap between the work of lawyers and that of other professionals. Accountants, bankers, real estate agents, invest-

lable hours a year").

189 One might posit that clients could contract around this problem by agreeing to share their attorneys' work product. No doubt certain institutional repeat-players have adopted such cost sharing approaches. For most clients, however, such a tactic would be impossible. First, clients are at an information disadvantage. It would be difficult for all but the most sophisticated to ignore counsel's advice to maintain the secrecy of work product. Furthermore, each individual client would be handicapped by uncertainty, unable to predict whether the information provided would outweigh the information received. Thus, in the vast majority of cases the work product privilege effectively protects the attorney's intellectual capital from appropriation by either the opposition or the attorney's own client.

${ }^{190}$ Upjohn extends the attorney-client privilege beyond the so-called "control group" to cover employee communications relevant to the subject matter of the litigation. See Upjohn, 449 U.S. at 394-95 (holding that corporate employees' communications to the counsel for the corporation are protected by the attorney-client privilege). Furthermore, in many situations the Rules of Professional Conduct operate to prohibit an attorney from interviewing the employees of an opposing corporation. See, e.g., MODEL RULES OF PROFESSIONAL CONDUCT Rule 4.2 (1983) ("In representing a client, a lawyer shall not communicate about the subject of the representation with a party the lawyer knows to be represented by another lawyer in the matter, unless the lawyer has the consent of the other lawyer or is authorized by law to do so."); Alexander, supra note 146, at 230 (noting that opposing counsel is rarely granted permission to interview corporate employees). But see ABA Comm. on Ethics and Professional Responsibility, Formal Op. $91-359$ (1991) (interpreting Model Rule 4.2 as not extending to contact with former employees of an adverse corporate party).

${ }^{191}$ Again, clients might attempt to avoid unnecessary deposition taking, but they face the same information deficits discussed supra note 189. 
ment counselors, tax preparers, estate planners, private investigators, business advisors and others all offer some of the same services as attorneys. To their competitive advantage, ${ }^{192}$ lawyers alone are able to offer guaranteed secrecy-secured by their access to both the evidentiary privileges and the ethical confidentiality principle.

The accounting profession provides a useful case in point. Both lawyers and accountants are capable of preparing tax returns and providing tax planning advice. Indeed, the work of the two professions is often identical. Accountants, however, do not have the same broad access to secrecy rights as do lawyers. There is no common law testimonial privilege for accountants. ${ }^{199}$ Although a number of states have enacted statutory accountant-client privileges, these are typically far weaker than the attorney-client privilege. ${ }^{194}$ Moreover, no accountant-client privilege obtains in federal court, ${ }^{195}$ nor is there federal work product protection for accountants' opinions, conclusions or papers. ${ }^{196}$

Thus, information provided to accountants is vulnerable to compelled disclosure, notwithstanding its potentially "sensitive and confi-

192 See Alexander, supra note 146, at 282 (noting one attorney's belief that access to privilege creates a "competitive edge over accountants").

For a stark example, consider Estate of Murphy v. Commissioner, 60 T.C.M. (CCH) 645 (1990), in which the Tax Court denied favorable tax treatment to an estate to the tune of somewhere between one million and three million dollars. See id. at 648. Specifically, the court held that the decedent, on the advice of her accountant and tax advisor, had made certain gifts of stock purely to reduce the federal transfer tax and not actually to divest herself of control of a closely held corporation. See id. As proof of the decedent's invalid intent, the Tax Court relied on a series of communications between the decedent and her accountant. See id. at 647-48. In contrast, had the estate planning advice come from an attorney, the content would have been privileged and therefore unavailable to the Tax Court. See Hitt v. Stephens, 675 N.E.2d 275-78 (Ill. App. Ct. 1997) (holding that estate planning documents are protected by the attorney-client privilege, even 40 years after the testator's death). The lesson of this cautionary tale is that confidentiality is worth money-in Estate of Murphy, rightly or wrongly, over a million bucks-and that the attorney-client privilege can be well worth whatever it costs.

${ }^{193}$ See Couch v. United States, 409 U.S. 322, 335 (1973) (“[N]o confidential accountant-client privilege exists under federal law, and no state-created privilege has been recognized in federal cases." (citations omitted)).

${ }^{194}$ See Gary Lawson \& Tamara Mattison, A Tale of Two Professions: The Third Party Liability of Accountants and Attorneys for Negligent Misrepresentation, 52 OHIO ST. L.J. 1309, 1315 (1991) (noting that about one-third of the states have statutes protecting accountant-client communications).

195 See Conech, 409 U.S. at 335.

196 See United States v. Arthur Young \& Co., 465 U.S. 805, 817 (1984); Fisher v. United States, 425 U.S. 391, 405, 414 (1976). 
dential" nature. ${ }^{197}$ One simply cannot entrust work to an accountant with any secure expectation that it will remain private and personal. ${ }^{198}$ Consequently, a certain volume of work, where inviolability is prized, will necessarily be transferred from relatively lower-price providers to higher-price attorneys. ${ }^{199}$

\section{Summary}

We recognize that the public assets theory is not wholly distinct from the monopoly theory of pro bono obligations. Both approaches derive from the recognition of attorneys' unique access to the courts and other aspects of the practice of law. To that extent, one might even regard the public assets analysis as an elaboration upon or refinement of the more venerable monopoly theory.

We believe, however, that we go well beyond the monopoly theory in our examination and understanding of the public's direct contribution to lawyers' capital, and therefore to lawyers' fees.

\section{CONDITIONED ACCESS TO INFORMATION-ASSETS: OTHER EXAMPLES}

The nub of our theory is that lawyers have exclusive access to certain publicly created information-assets, and that a pro bono obligation may be extracted as a condition of their use. A requirement of pro bono legal work is a type of in-kind exchange. The public assets enhance the lawyer's legal services for paying clients, in return for which the lawyer may be expected to provide a small amount of simi-

197 See Lawson \& Mattison, supra note 194, at 1314-15 (noting that an "accountant's work product ... is not protected by common-law evidentiary privileges"); see also Estate of Murphy, 60 T.C.M. (CCH) at 647-48, 658 (denying favorable estate tax treatment on the basis of decedent's apparent intent, as revealed by "less than subtle" advice letters from decedent's accountant).

198 But of. Couch, 409 U.S. at 342 (Douglas, J., dissenting) (criticizing the majority's decision to compel disclosure of client documents in the possession of an accountant as encouraging not "trusting anyone with even temporary custody of documents we want to protect from public disclosure").

${ }^{199}$ A comparable phenomenon exists with regard to fact investigation. When conducted by nonlawyers, fact investigation, even when carried out in contemplation of litigation, is not protected from compelled disclosure. See United States v. Rowe, 96 F.3d 1294, 1297 (9th Cir. 1996). On the other hand, if lawyers are engaged to pursue an investigation, virtually all communications are protected, even where there is no specific retention for the purpose of providing legal advice. See id. (noting that "factfinding which pertains to legal advice counts as "professional legal services'" and holding that communications to a partner by young associates asked by the partner to investigate another attorney's conduct to the partner are privileged). 
lar services free of charge.

This sort of conditioned, in-kind payment is hardly unknown in other contexts-particularly where the commodity involved is a form of information. While none of the examples that follow are entirely congruent with the provision of legal services, we think that they amply illustrate and support the principle underlying the public assets theory.

\section{A. Communications}

The Communications Act of $1934^{200}$ and the Telecommunications Act of $1996^{201}$ both provide examples of in-kind obligations imposed upon recipients of public-information assets. Under both statutes, the government grants broadcasters the right to use publicly owned frequency bands at no cost. Broadcasters then resell their access to advertisers. In exchange for this use, broadcasters have been required to provide a variety of in-kind services. The broadest such provision is the general requirement that licensees operate their frequencies as "public convenience, interest, or necessity" requires, ${ }^{202}$ as determined by the Federal Communications Commission ("FCC"). ${ }^{203}$

The so-called "Fairness Doctrine" was perhaps the most well known in-kind condition imposed upon broadcasters. It exacted multiple content obligations in exchange for a broadcast license: licensees were required to present conflicting views of public issues and if no person was willing to pay to air a dissenting opinion, the broadcaster had to present it free of charge. ${ }^{204}$ The Personal Attack Rule mandated equal time (at no charge) for people who had been "attacked" on air, ${ }^{205}$ as well as a free transcript, recording or summary of the criticism. ${ }^{206}$

${ }^{200} 47$ U.S.C. $\$ 151$ (1994).

20147 U.S.C.A. $\$ 254$ (West 1997).

20247 U.S.C. $\$ 307$ (a) (1994).

${ }^{203}$ See 47 U.S.C.A. $\$ 315$ (a) (West 1996); see also Lechtner v. Brownyard, 679 F.2d 322, 325 ( $3 \mathrm{~d}$ Cir. 1982) (noting that the Fairness Doctrine requires licensees to "operate in the public interest" and to "present public questions fairly and without bias").

See Cullman Broad. Co., 40 F.C.C. 576, 577 (1963) (stating that a licensee may not refuse to broadcast an opposing viewpoint just because she cannot obtain paid sponsorship for it).

${ }^{205}$ See 32 Fed. Reg. 10,303, 10,304 (1967) (requiring the licensee to notify the person attacked of her opportunity to respond on the air).

${ }^{206}$ See Red Lion Broad. Co. v. FCC, 395 U.S. 367, 372-80 (1969) (noting that the FCC required licensees to send a tape, transcript or summary of the critical broadcast 
The Fairness Doctrine and Personal Attack Rule were enforced by the FCC, even to the extent of denying a license renewal as the consequence of repeated violations. ${ }^{207}$ In Brandywine-Main Line Radio, Inc. v. $F C C{ }^{208}$ the licensee broadcast controversial programs "without presenting any opposing viewpoints" and failed to establish any regular procedure for previewing, monitoring, or reviewing its broadcasters. ${ }^{200}$ The Court of Appeals for the District of Columbia Circuit affirmed the FCC's refusal to renew the broadcast license, stating that the broadcaster had an "affirmative duty" to comply with the mandates of the FCC, even if there were attendant costs, because this was a reasonable condition of licensed access to the public airwaves. ${ }^{210}$ In broader terms, the right to resell a public commodity was conditioned on the provision of in-kind services.

The Supreme Court upheld the constitutionality of both the Fairness Doctrine and the Personal Attack Rule in Red Lion Broadcasting Co. v. FCC. ${ }^{211}$ Although the FCC abolished the Fairness Doctrine in $1987,{ }^{212}$ Red Lion continues to elucidate the acceptability of imposing in-kind obligations in exchange for the exploitation of information-assets. Indeed, Congress has continued to exact other such requirements of broadcast licensees.

The Telecommunications Act of $1996^{213}$ extracts numerous inkind obligations from Internet providers. For example, the Act requires recipients of electronic ("Internet") rights to provide advanced telecommunications services to schools, hospitals and other qualified agencies. ${ }^{214}$ Upon receipt of a bona fide request, a telecommunica-

to the critiqued individual).

${ }^{207}$ See Brandywine-Main Line Radio v. FCC, 473 F.2d 16, 29 (D.C. Cir. 1972), cert. denied, 412 U.S. 922 (1973) (noting that the FCC rejected a license renewal application in part because the broadcaster failed to comply with the Fairness Doctrine and the Personal Attack Rule on numerous occasions).

${ }^{208}$ Id.

${ }^{209} I d$. at $29-30$ (citation omitted).

${ }^{210}$ Id. at 50 (stating that the broadcaster's preferred defense for not screening tapes prior to broadcast-the small size of its staff-did not excuse it from compliance with FCC regulations).

211395 U.S. 367, 400 (1969) (noting the constitutionality of the Fairness Doctrine and the Personal Attack Rule given the governmental interest in ensuring a range of programming wide enough to serve the public interest).

${ }_{212}$ See Syracuse Peace Council, 2 F.C.C.R. 5043, 5052 (1987) (holding that the Fairness Doctrine violates the First Amendment due to its "chilling effect" on "the editorial processes of broadcast journalists").

${ }_{213}^{213} 47$ U.S.C.A. $\$ 254$ (West 1997).
See id. $\$ \$ 254($ b) (6), (d). 
tions carrier must also supply services at nonmarket rates to healthcare providers in rural areas. ${ }^{215}$ Other reduced-rate provisions apply to schools and libraries. ${ }^{216}$ In the terms of the Telecommunications Act, "these and other service obligation [s]" form part of a carrier's "obligation to participate in the mechanisms to preserve and advance universal service." ${ }^{217}$ In short, the Telecommunications Act of 1996 mirrors our public-assets theory: it grants a right to resell access to an information-resource, carrying with it a duty to provide a designated level of in-kind services.

\section{B. Scientific Research}

State and federal government benefits take a variety of forms, including access to facilities, rights of exploitation, goods, services and cash. $^{218}$ The federal government provides a large amount of funding for research in various scientific disciplines, ${ }^{219}$ usually conditioning its grants on the return of in-kind information services. The National Science Foundation ("NSF"), for example, annually awards billions of dollars ${ }^{220}$ to support scientific research by as many as 10,000 recipients. ${ }^{221}$ While the NSF is fairly open in its award policies, its grants are consistently accompanied by in-kind information-sharing conditions.

${ }^{215}$ See id. $\$ 254(\mathrm{~h})(1)(\mathrm{A})$.

${ }^{216}$ See id. $\$ 254(\mathrm{~h})(1)(\mathrm{B})$.

${ }^{217}$ Id. $\S 254(\mathrm{~h})(1)(\mathrm{A})$. Additional service obligations, which may be defined under the FCC's rulemaking power, include the provision of defined services, including the connection of network access to public schools, hospitals, health care providers and other not-for-profit agencies. See id. $\$ 254(\mathrm{~h})(2)(\mathrm{B})$.

${ }^{218}$ See Gary Feinerman, Note, Unconstitutional Conditions: The Crossroads of Substantive Rights and Equal Protection, 43 STAN. L. REV. 1369, 1369 (1991). Feinerman also identifies tax exemptions as a category of government benefit. See id. This view is not uncontroversial. We agree with Feinerman, however, that the allowance of an exemption to some (and not others) ought to be considered a benefit-even if the benefit consists entirely of not being bled.

${ }^{219}$ See Peter Brody, Confidentiality Clauses in Research Contracts and Grants: Are They "Unconstitutional Conditions"?, 22 PUB. CONT. L.J. 447, 447 (1993) ("The federal government is a source of substantial funding for research in the physical and social sciences.").

${ }_{220}$ In 1991, the NSF awarded approximately $\$ 2.2$ billion in grants and contracts. See National Science Foundation Grants Management: Hearing Before the Senate Comm. on Governmental Affairs, 102d Cong. 16 (1991) [hereinafter NSF Hearing] (testimony of Dr. Frederick M. Berthol, Deputy Director, NSF) (stating that in 1991 over 95\% of NSF's $\$ 2.3$ billion budget went toward grants and contracts).

221 The NSF annually receives in excess of 40,000 applications, which eventually result in about 10,000 awards. NATIONAI SCIENCE FOUND., NSF 95-27, GRANT PROPOSAL GUIDE at i (1995) [hereinafter NSF Grant Proposal Guide]. 
Recipients are typically required to publish their findings or to permit their research to be freely used by others. ${ }^{222}$

The NSF defines a grant as:

a type of assistance award and a legal instrument which permits an executive agency of the Federal government to transfer money, property, services or other thing of value to a grantee when no substantial involvement is anticipated between the agency and the recipient during the performance of the contemplated activity.

By any definition, a grant is a public resource. For our purposes, it is significant that NSF grants are provided without a subsequent expectation of involvement between the agency and the recipient of the subsidy. Thus, the public asset (in this case, money) is made available for independent, unsupervised exploitation by nongovernmental actors.

Although the relationship to lawyers' use of confidentiality rights is strictly by analogy, some parallels are evident. NSF grants, of course, are intended to facilitate and encourage the work of the scientists who receive them, ${ }^{224}$ just as confidentiality rights are rationalized as enabling lawyers to better serve their public function. ${ }^{225}$ Federal grants provide direct income support to recipients, while confidentiality protection indirectly enhances lawyers' fees. ${ }^{226}$ The public pays for NSF grants through the expenditure of tax dollars, and bears the costs of lawyer confidentiality in the form of increased litigation expenses and the suppression of truth. ${ }^{227}$ Perhaps the greatest similarity though, lies in the fact that both public assets are made available for the purpose of expanding the recipients' abilities to gather and use information.

${ }^{222}$ Recipients are required to provide periodic reports on the development of their research, and also to submit detailed reports at the conclusion of the work for which they receive funds. See NATIONAL SCIENCE FOUND., NSF 95-26, GRANT POLICY MANUAL paras. 341-43, at III-6 (1995) [hereinafter NSF Grant Policy Manual]; NATIONAL SCIENCE FOUNDATION FINAL PROJECT REPORT, Form 98-A. It is also expected that an article or paper, written by the principal investigator, will "be completed in some sort of formal document." NSF Hearing, supra note 220, at 8 (testimony of Judy England-Joseph, Associate Director, Energy Issues, Resources, Community and Economic Development Division, General Accounting Office).

${ }^{223}$ NSF Grant Policy Manuah supra note 222, para. 210(c), at II-1.

${ }^{224}$ See National Science Foundation Act of 1950, 42 U.S.C. $\$ 1862$ (a) (1994) (stating that the NSF "initiate[s] and support[s] basic scientific research" through the use of grants, loans and other means of aid).

See supra Part II.A.1.

${ }^{226}$ See supra text accompanying note 119.

227 See supra Part II.A.1. 
In that light, consider the NSF's "sharing policy." Under this policy, grant recipients are expected to share information with the general public, other researchers and the scientific community. ${ }^{228}$ The sharing obligation extends to primary data, samples, physical collections and other supporting materials that may be of interest or use to other researchers. ${ }^{229}$ Additionally, grant recipients operate under a "formal requirement" that they disseminate their results throughout the scientific community through publication of "all significant findings" at the conclusion of the grant period. ${ }^{230}$ Grantees may be denied future awards, or even be suspended or terminated, for failure to comply with terms and conditions, including the communication of findings. ${ }^{231}$

NSF grantees profit directly from their awards by receiving cash stipends, while lawyers profit indirectly from access to confidentialityassets by reselling them to clients. We do not believe that this distinction makes a difference that has any bearing on our theoryespecially since we offer the NSF comparison only as an analogy. Nonetheless, it may be pointed out that NSF grantees, like lawyers, can resell the benefits of the information generated by their research, thus profiting indirectly as well as directly. ${ }^{232}$ The government does not assume ownership of the research products that result from NSFfunded projects. The grantees are permitted to retain principal rights to the intellectual property, although this right is not intended to reduce the investigators' responsibility for sharing and disseminating information. ${ }^{233}$ The NSF will not take any part of the income earned from copyrightable material. ${ }^{234}$ Moreover, a recipient is generally allowed the first right to a resulting patent, except in certain basis. Id.

${ }^{228}$ NSF Grant Proposal Guide, supra note 221, para. H, at 22.

${ }^{229}$ Id. $\S 734$ (b). Exceptions to the sharing policy may be made on an individual

${ }^{230}$ NSF Grant Policy Manual, supra note 222, para. 734(a), at VI-11; NSF Hearing, supra note 220, at 24 (testimony of Dr. Frederick M. Bernthal, Deputy Dir., NSF) ("We do have a formal requirement that at the end of the grant period ... there be a short report ... that the research has been carried out.").

${ }^{231}$ Hearing, supra note 220, at 13, 27-28 (testimony of Sen. Daniel A Akaka \& Dr. Frederick M. Bernthal); NSF Grant Policy Manual, supra note 222, §912.1 (a) (1).

${ }^{232}$ NSF Grant Policy Manual, supra note $222, \S 753$ (a)(2) (no requirement that profits be used for continued research).

293 Id. para. 734(d), at VII-11.

${ }^{234}$ Id. paras. 732.2(b), 753(a) (1), at VII-9, VII-12. The government does retain authority to exercise a right to a royalty-free license on copyrighted material produced pursuant to government-funded research. Id. This exercise of such a public right to information, of course, further supports the public-assets theory. 
specific situations. ${ }^{235}$

Thus, the federal government goes to great lengths to encourage the accumulation of scientific information. The right to exploit intellectual property translates into a strong incentive to engage in research and development. The federal government, by extending these information-assets to grantees, enables the recipients to profit economically from their original access to public resources-though requiring a small in-kind recompense in the form of information sharing. In our view, mandatory pro bono representation is the lawyers' analog to the scientists' dissemination obligation.

\section{Other Examples}

Without belaboring the point, there exist numerous other examples of in-kind exchanges for the right of access to public resources or assets. Hospitals that receive federal funding must "furnish needed services for persons unable to pay therefor." ${ }^{236}$ University and college libraries that have been granted federal depository status receive government publications at no cost, unlike all other libraries which must pay for the same publications. In return, the federal depositories must agree to make the resources broadly available to the public. ${ }^{237}$

An interesting contrast, however, is provided in the practice of granting business concessions in national parks. Concessionaires in national parks clearly benefit from the "resale" of their location in spectacular, publicly owned natural settings. Under our theory, some of the rents derived from these unique sites would be returned to the public in the form of in-kind obligations. Under current law, however, businesses are granted concessions to operate in national parks with few reciprocal demands. They are not required to make im-

${ }^{235}$ See Bayh-Dole Act, 35 U.S.C. $\$ 202$ (a)-(b) (1994) (noting that the situations that might limit a contractor's retention of title include the absence of a United States contractor, "exceptional circumstances," and possible danger to national security).

${ }^{236}$ See Hill-Burton Act, 42 U.S.C. \$ 291c (e) (1994). The Surgeon General is authorized under the Act to issue regulations that facilitate access to hospitals by those who are unable to pay for the services. See id. The current regulations require hospitals to provide uncompensated care, and set a yearly standard of either $3 \%$ of a facility's operating costs or $10 \%$ of all federal assistance received by the facility. 42 C.F.R. $\S 124.503(\mathrm{a})$ (1996).

${ }^{237}$ FEDERAL DEPOSITORY LIBRARY PROGRAM, Federal Depository Library Manual: Guidelines for the Federal Depository Program § 8-1 (Supp. II 1996). These obligations include reference assistance to the public, the appointment of a "professionally qualified librarian" to coordinate depository activities, and the employment of sufficient staff. Id. $\$ \S 6,8-2$. 
provements to the land, but they are granted possessory rights to the improvements that they do make. ${ }^{238}$ They also benefit from a "right to renew ${ }^{239}$ the concessions contract, which "effectively grants concessionaires 'ownership' of the operating rights in a given park in perpetuity. ${ }^{240}$ In other words, national park concessionaires are given access to exploit public assets, but are not presently required to make in-kind contributions in return.

A bill now pending in the House of Representatives, however, would impose in-kind obligations on national park concessionaires. ${ }^{241}$ Under the proposed legislation, concessionaires would be required to make physical improvements in exchange for the right to conduct their businesses in the national parks. ${ }^{242} \mathrm{~A}$ further provision would require concessionaires to pay into a fund specifically earmarked for the upkeep and improvement of the parks in which they operate. ${ }^{245}$ Finally, the "right to renew" would be eliminated, replaced with a system of preferences dependent upon the concessionaire's matching the terms and conditions of the optimal competing proposal. ${ }^{244}$

The debate over the concessions-reform legislation clearly reflects dissatisfaction with a current system that is based, in part, on concessionaires' seemingly unrestrained right to capitalize public assets without returning in-kind benefits to the government. If successful, these reform efforts will lead to a new approach that has much in common with our proposal for mandatory pro bono representation by attorneys.

${ }^{233}$ See National Park System Concessions Policy Act, Pub. L. No. 89-249, 79 Stat. 969,970 (1965) (codified as amended at 16 U.S.C. $\$ \S 20-20 \mathrm{~g}(1970)$ ).

${ }^{239}$ See 16 U.S.C. $\$ 20$ d (granting a renewal preference to concessionaires who fulfill their obligations satisfactorily).

${ }^{240}$ United States Dep't of Interior, Report of the Task Force on National Park Service Concessions 10 (Apr. 9, 1990), cited in National Park Concessions Policies and Management: Oversight Hearings Before the Subcomm. on National Parks and Public Lands of the Comm. of Interior and Insular Affairs, House Comm. on Interior and Insular Affairs, House of Representatives, 101st Cong. 12-16 (1990) (testimony of James R. Richards, Inspector General, U.S. Department of the Interior).

${ }_{241}$ See National Park Scenic Overflight Concessions Act of 1995, H.R. 1954, 104th Cong. This bill is based on H.R. 773, National Park Service Concession Policy Reform Act of 1995, 104th Cong. (1995), and H.R. 721, Public Resources Deficit Reduction Act of 1995, 104th Cong. $\$ 500-17$ (pertaining specifically to concessions). These two resolutions have overlapping provisions on concessions policy.

${ }^{242}$ See H.R. 773 § 12.

245 See id. $\$ \S 8,9$.

${ }^{244}$ Id. $\$ 7$, at 8 . 


\section{ARguments Against MaNdATORY PRO BoNo PlanS}

At this point we have developed the intellectual infrastructure for the public assets theory. We have shown that lawyers are the recipients of certain publicly created commodities which they resell to their clients. This resale enables attorneys to charge premium fees that are unavailable to practitioners in other law-related professions. The institution of a compulsory pro bono plan would allow the public to recapture some of the lawyers' rents in kind, by requiring the sharing of lawyers' intellectual capital. We are confident that our theory rigorously justifies mandatory pro bono plans in a way that previous conceptions have not.

Having demonstrated the conceptual validity of pro bono plans, however, there remains what might be called the prudential question. Are pro bono plans a good idea? Will they effectively serve a useful purpose? To answer this inquiry, we turn to the arguments that have been raised against pro bono plans in the past.

\section{A. Efficiency}

Perhaps the most forceful argument against the desirability of pro bono plans was made by Professor Jonathan Macey, who argued that such programs, far from achieving their stated goals, would actually harm the poor. ${ }^{245}$ In Macey's view, mandatory pro bono plans are not merely misguided, but actually "odious and unethical."246

Macey's principal argument in this regard is that the result of increased legal services would be to raise the cost to the poor of necessities such as housing. He summarizes his position as follows:

With the possible exception of matrimonial work, lawsuits against landlords are expected to occupy the lion's share of the time that lawyers compelled to provide legal services for the poor would spend on mandatory pro bono. If more marginal lawsuits are brought against landlords because lawyers need something to do to fulfill their mandatory pro bono obligations, the landlords' costs of providing housing to the indigent inevitably will go up. As the cost of providing housing goes up, rents will increase and the supply of housing for the poor will go down. ${ }^{247}$

${ }^{245}$ See Macey, supra note 33, at 1116-18 (discussing how mandatory pro bono plans would drive up housing costs and thereby diminish affordable housing for poor people).

246 Id. at 1116.
247 . at 1118 . 
This argument fails utterly once we unwind its many loop-back assumptions. First, Macey assumes without support, that the "lion's share" of pro bono attorney time might be spent on suits against landlords. In truth, this is extremely unlikely. Most existing legal services offices spend relatively small amounts of time on landlord cases. For example, the legal services organization for Ithaca, where Macey works, devotes only $17 \%$ of its time to housing matters; ${ }^{248}$ at the Legal Assistance Foundation of Chicago the figure for all evictions (including public housing) is under $9 \% .{ }^{249}$ The percentages are important, since the best available assumption is that they would be carried through into pro bono efforts. Thus, a twenty hour pro bono quota in New York might translate into three or four hours a year devoted to suing landlords. ${ }^{250}$ In Illinois, the figure arguably would be two hours or less. Of course, in most locations the legal markets are dwarfed in size by the housing markets. Consequently, if the average lawyer ends up spending as many as six pro bono hours on housing cases, and even if the full cost generated by that representation is passed on to tenants, ${ }^{251}$ the net measurable impact on the housing

${ }^{248}$ Ithaca, New York is served by Tompkins/Tioga County Legal Services. Of 1196 cases closed by that agency in 1995, 204 (17\%) were classified as "housing." Of these, it is probable that the overwhelming majority resulted in negotiated settlements, since only $26 \%$ of the agency's overall caseload involved litigation and a mere $8 \%$ were tried to verdict. Letter from Mark Freedman, Staff Attorney, Tompkins/Tioga County Legal Services, to Steven Lubet (Aug. 26, 1996) (on file with authors).

${ }^{249}$ Legal Assistance Foundation of Chicago, Overall Activity Summary (Jan. 1 Dec. 31, 1996). The figure for private evictions, which seem to be Macey's principal concern, is only $7 \%$. Id.

${ }^{250}$ Macey's article was written in response to the Marrero Committee Report, supra note 25, which called for every lawyer to spend 20 hours per year on pro bono representation. See Macey, supra note 33, at 1115 (noting that the report issued by the Marrero Committee pushed the issue of mandatory pro bono representation to the surface). If fully $20 \%$ of those cases turn out to be landlord matters, the net result would be four hours per year per lawyer. A figure of $17 \%$ would result in only 3.4 hours per year.

Macey indulges the assumption that the costs associated with pro bono work will be passed through to tenants, but it is unsupportable. See infra note 257-59 and accompanying text. Actually, it is difficult to say just how pro bono representation might affect landlords. Macey believes that mandatory pro bono hours will result in increased litigation that will have to be defended by paid counsel. See Macey, supra note 33, at 1119 (stating that pro bono attorneys will represent plaintiffs, forcing defendants to hire counsel to represent them). The New York plan that Macey assailed called for every lawyer to devote 20 hours per year to uncompensated legal work. See supra note 250 . Assuming a one-to-one equivalence, that means that the average landlord lawyer would have to devote less than 30 minutes a week to defending the additional cases-and that assumes that all of the pro bono hours will be spent on litigation. It is inconceivable that such a minimal expenditure could have any perceptible 
market nonetheless will be negligible to nonexistent.

Professor Macey's second assumption is that pro bono lawyers will bring "marginal" law2 lawsuits, which Macey characterizes as "complicating evictions of nonrent-paying [sic] tenants." ${ }^{253}$ This statement reflects ideological bias more than empirical investigation. In fact, one survey indicates that a great majority of unrepresented eviction defendants had potentially valid defenses-including actual payment of rent-that they were unable to assert without counsel. ${ }^{254}$ Under these circumstances, representation should be characterized not as marginal, but as law enforcement. ${ }^{255}$

Macey's third assumption is that costs to landlords "inevitably will go up. "256 We have already seen that this is untrue in any but the most attenuated sense. Actual housing costs would almost certainly be entirely unaffected by even the most ambitious pro bono plan. Macey, however, goes even further, positing that the hypothetical increase in housing costs will result in increased rents to the poor. ${ }^{257}$ In other words, he assumes a fully elastic demand for low-income housing such that all landlords will be able to pass all of their presumedly increased costs through to their tenants. But poor tenants, by definition, operate on limited incomes, and thus landlords (or their lawyers) might

impact on housing prices. There is also the possibility that landlords would incur additional expenses apart from litigation costs, although Macey does not address this. Some such costs would no doubt come in the form of increased compliance with building codes, which is exactly the sort of public good that Macey expects litigation to accomplish. See Macey, supra note 33 , at 1118.

${ }_{252}^{25}$ Macey, supra note 33, at 1118.

${ }^{233}$ Id. (citing John A. Humbach, Serving the Public Interest: An Overstated Objective, 65 A.B.A. J. 564, 566 (1979)).

${ }_{254}$ Marrero Committee Report, supra note 25, at 773 (noting that, in all the reported cases where pro bono representation was provided, no evictions were reported); see also Millemann, supra note 29 , at 26 (concluding that many inner-city defendants in summary eviction proceedings have meritorious defenses).

${ }^{253}$ Macey expands on his "marginal case" theory by arguing that paying clients will only bring cases where the expected benefit outweighs their cost, but that pro bono clients, freed from this constraint, will pursue meritless cases. As he puts it, "[i]n the case of pro bono lawyering, however, the cost of mounting litigation is reduced to zero." Macey, supra note 33, at 1118 . This analysis ignores the lawyers' costs. There is no reason to think, and certainly Macey provides none, that pro bono lawyers will routinely choose to bring meaningless cases. Required to devote, say, 20 hours a year to uncompensated representation, why would lawyers not opt to bring the cases that of- . fer the greatest nonmonetary rewards? Free to choose among nonpaying clients, why would lawyers not decide to accept the most worthy, meritorious, potential winners among them?

\footnotetext{
${ }^{256} I d$.

257 See id.
} 
well have to eat whatever slight costs might be associated with pro bono representation.

Professor Macey makes two further efficiency arguments. First, he contends that pro bono plans are unnecessary, because poor people already are receiving the optimum level of legal services. ${ }^{258} \mathrm{He}$ also claims that mandatory pro bono programs would result in unfair wealth transfers from solo practitioners to big firms. ${ }^{259} \mathrm{He}$ is wrong in both regards. Macey explains that poor people do not receive legal services because they choose to spend their limited resources on more pressing needs, such as food and shelter. ${ }^{260}$ From this he concludes that pro bono plans are "wasteful and inefficient," since any rational poor person would obviously prefer a direct cash transfer of even $\$ 2500$ to twenty hours of services from a Wall Street partner, which Macey values at around $\$ 10,000 .^{261}$ This argument proves too much. Individual indigents would no doubt prefer cash transfers to all manner of in-kind services, ranging from garbage collection to police protection to park maintenance. But just as in the case of police protection, the sum social benefits of broadened legal services may be greater than the distinct value to individual recipients. ${ }^{262}$ Macey him-

${ }^{258}$ See id. at 1116-17 (stating that the reason why poor people do not seek legal services is because they are "rational" and would rather spend their money elsewhere).

${ }^{259}$ See id. at 1119-20 (finding that mandatory pro bono would cause defendants to have to hire counsel, usually at large firms, thereby giving them added wealth).

260 See id at 1116.

${ }^{261}$ See id. at 1117. There is a further flaw here. Macey sets the retail value of a partner's time at $\$ 500$ per hour, although this is extravagant for all but a very few attorneys. See Weidlich, supra note 26, at A5 (stating that according to an international survey, attorneys in the U.S. bill between $\$ 200$ and $\$ 400$ per hour, with $\$ 400$ per hour listed as a "top hourly rate"). In any event, whatever rate might be billed to clients, the net incremental cost of pro bono time to the law firm is probably closer to zero. That is, virtually no law firms turn away paying clients, particularly at $\$ 500$ per hour. Instead, they either work harder, longer, more efficiently or they increase capacity. Thus, the expenditure of 20 hours on pro bono representation would not result in lost billings. Indeed, the pro bono client could receive more benefit from the lawyer's time than the lawyer would lose in income. Voilà, efficiency.

It is particularly ironic that Macey made this argument while simultaneously positing "that the big push for mandatory pro bono is coming from big firm lawyers at a time when demand for the services of those firms is lagging appreciably behind the available supply." Macey, supra note 33, at 1119. Though Macey failed to acknowledge it, the utilization of a firm's existing excess capacity would cost the firm little or nothing. Hence, even on Macey's terms it is fallacious to conjecture that pro bono time has a cost of $\$ 500$ per hour.

${ }_{262}$ Additionally, as we demonstrated earlier, there is a strong case for requiring lawyers to donate in-kind services as compensation for their access to publicly created information assets. The case for direct cash transfers, however, would be weak. Thus, the choice for the poor is not between lawyers and cash, but between lawyers and 
self recognizes this with regard to paying clients when he observes that "[l]itigation often produces benefits . . . for society as a whole because individuals who expect to pay damages for the harm they cause have an incentive to reduce their harmful activities." ${ }^{263}$

But Macey's "optimum services" argument is wrong in an even more fundamental way. He believes that poor people spend little money on lawyers because they place a low value on legal services. It is equally plausible, however, that they value legal services at a reasonable level, but still cannot afford them due to competition from businesses and well-to-do individuals. That is, given a finite number of attorneys, poor people must compete for their time with corporations and wealthy people who are in a position to bid up the price. Since, as we have seen, part of the price of lawyers is attributable to publicly created assets, it is not unreasonable to make some small amount of the resulting services available at nonauction prices. ${ }^{264}$

Finally, Professor Macey suggests that pro bono plans are part of a seemingly sinister effort ${ }^{265}$ to transfer income from small firm practi-

\footnotetext{
nothing
}

${ }^{263}$ Macey, supra note 33, at 1118.

${ }^{264}$ Our social structure does not expect poor people to compete at auction for sanitation, minimal medical services, education or other necessities. We realize that the characterization of legal services as a necessity is controversial in some quarters. Professor Macey, for example, believes that, because poor people have slight or negative net worth, it would be irrational for them to engage lawyers to represent them in divorce proceedings. See $i d$. at $1117-18$ ("When there is simply no material estate to fight over, it does not make sense to hire lawyers as combatants." ). True enough, one does not need an attorney to do combat over a nonexistent estate. But how, pray tell, will the indigent become divorced without lawyers? Self-representation ranges from risky to impossible, especially where there are issues of child custody, support and visitation.

We are confident, therefore, that no one would argue that legal representation is always nonessential. Thus, the question becomes one of case selection. We are comfortable with the proposition that pro bono services ought to be devoted to primary legal needs.

${ }^{265}$ Macey intimates something approaching a conspiracy: "It is no coincidence," he cautions, "that the big push for mandatory pro bono is coming from big firm lawyers at a time when demand for the services of those firms is lagging appreciably behind the available supply." Id. at 1119. So, supposedly, big law firms are foisting pro bono plans on the entire bar just so that they can make work for their idle associates. This is a scenario worthy of Oliver Stone. The reality is far different. Large law firms have a much easier and cheaper way of dealing with excess capacity. They can fire or lay off unnecessary associates, which is exactly what they did during the legal recession of the early 1990s. See Edward A. Adams, Firms Weather the Recessionary Storm: For Some It Was a Tempest in a Teapot, N.Y. L.J., Nov. 7, 1994, at S3 (recounting associate layoffs); Edward A. Adams, Milbank Lays Off 29 Senior Associates, NAT'L L.J., Feb. 17, 1992, at 2; Edward A. Adams, Skadden Arps Pink Slips 45 Associates, NAT'L L.J., Oct. 7, 1991, at 2; Susan Freinkel, Chapman $\&$ Cutler Cuts 17, AM. LAw., May, 1995, at 14. 
tioners to the upper-strata elite, who will be the "real beneficiaries of mandatory pro bono programs. ${ }^{\text {,66 }}$ This transfer will occur, says Macey, because the increased efficiencies of big firm practice will allow elite lawyers to cope more easily with the demands of any pro bono plan. Big firms can shift personnel, but solo practitioners cannot; big firms can amortize their costs more easily than small firms; "buyout" provisions favor larger offices. ${ }^{267}$ All of this is true. ${ }^{263}$ As an economist, though, Macey should understand that the very purpose of lawyers combining into a large firm is to create competitive and other advantages. So it should be no surprise that big firms will have an advantage when it comes to adjusting to pro bono plans. But Macey never explains why this should be considered unfair, much less an income transfer. Large firms also have an advantage when it comes to amortizing the cost of computers or assigning secretarial work, but no one sees a wealth transfer operating when courts require that pleadings be typewritten or printed. In any event, large firms and small firms almost never compete for the same business, ${ }^{269}$ so even proven disadvantages to small firms would not actually transfer wealth to Wall Street.

Macey also thinks that mandatory pro bono plans will increase the demand for big firm lawyers, by requiring their clients to defend more lawsuits. ${ }^{270}$ Here he has it completely backwards. If anything, a pro bono plan will create work for smaller firms. Large law firms do not typically engage in run-of-the-mill tenant disputes, but solo practitioners do. To the extent that a pro bono plan actually encouraged elite lawyers to represent tenants in evictions, the lawyer-beneficiaries

As to the suspicious "coincidence," Macey himself notes (twice) that debates over pro bono obligations "have been around for about as long as the world has been inhabited by lawyers and poor people." Macey, supra note 33, at 1115. For example, in 1981 , at a time when there was no apparent lag in the demand for big firm legal services, the ABA's Kutak Commission proposed a mandatory pro bono requirement of 40 hours per year per lawyer. See Schneyer, supra note 14, at 113-14. How would Macey explain that "coincidence"?

${ }^{206}$ Macey, supra note 33, at 1119.

${ }^{267}$ See id. at 1120 (listing ways in which a mandatory pro bono program will increase demand for lawyers in large firms).

${ }_{269}$ See Silverman, supra note 82, at 1001-11 (describing possible adverse effects of pro bono plans on smaller law firms and concluding that the effects are impossible to predict).

${ }^{269}$ See John P. Heinz \& EdWard Laumann, ChICAgo Lawyers: THE Social STRUCTURE OF THE BAR 130-31 (1982) (concluding, based on studies of the Chicago bar, that large firms primarily serve the corporate client sector and smaller law practices serve mostly individual clients).

${ }^{270}$ See Macey, supra note 33 , at 1119. 
would be the small firm practitioners who would no doubt delight in the increased demand for their (paid) services.

\section{B. Competence}

Opponents of pro bono plans often object that the legal work required will be too specialized or complicated for lawyers who have not specialized in poverty law or related fields. Justice Sandra Day O'Connor, for example, stated that a mandatory pro bono plan would be a "recipe for malpractice," since the lawyers involved would be unfamiliar and unwilling participants. ${ }^{271}$ With full respect to Justice O'Connor, we think that she underestimates lawyers and overstates her case.

First, it is simply wrong to think that special, esoteric legal skills are necessary to provide legal services to persons of limited means. Certainly, no novice should be asked to defend a capital felony ${ }^{272}$ or prosecute a welfare-rights class action, ${ }^{273}$ but the overwhelming majority of poor people have legal problems that are far more mundane. Wills, uncontested divorces, real estate closings, administrative hearings-this is the common fare of most poverty lawyers. These matters, and others like them, are hardly so complex that a reasonably competent attorney could not acquire the necessary proficiency in a very short time. ${ }^{274}$ Manifestly, "there is some kind of public service function which every lawyer can competently perform."

Indeed, Justice O'Connor herself went on to argue that the un-

${ }^{271}$ See O'Connor, supra note 2, at 3 ('I worry that the problem of quality control will plague any program of mandatory pro bono work.").

${ }_{72}$ See Christopher Hanson, Death Row Will Speed Up, But Injustices May Too, RockY MOUNTAIN NEwS, Nov. 19, 1995, at 14A (describing inexperienced and incompetent lawyers handling capital cases); Richard Lacayo, You Don't Always Get Perry Mason: As Coleman Goes to the Chair, Questions Remain About His Case and the Quality of Legal Defenders, TIME, June 1, 1992, at 38 (same); Stephanie Saul, When Death Is the Penally: Attorneys for Poor Defendants Often Lack Experience and Skill, NEwSDAY, Nov. 25, 1991, at 8 (noting that federal legislation requires states to appoint lawyers with at least five years of criminal defense experience to represent indigent death penalty defendants).

${ }^{273}$ Regarding the difficulty of locating competent attorneys to represent plaintiffs in poverty-related class-action litigation, see Nina Bernstein, Suit Challenges Accord that Bars Legal Services Class-Action Cases for Poor, N.Y. TIMES, Aug. 1, 1996, at D22.

${ }^{274}$ See Marrero Committee Report, supra note 25, at 811 (refuting the misconception that all indigent representation requires courtroom practice).

${ }^{273}$ Steven B. Rosenfeld, Mandatory Pro Bono: Historical and Constitutional Perspectives, 2 CARDOZO L. REV. 255, 266 (1981). Justice O'Connor seems also to recognize this. See O'Connor, supra note 2, at 5 (listing many areas of law in which pro bono services are needed). 
met need for pro bono services could be fulfilled by law students practicing in law school clinics. ${ }^{276}$ We are strong supporters of clinical legal education, but we still recognize that most lawyers are more adept than most students. Justice O'Connor's position is therefore self-defeating. If law students, in a single semester, can acquire the skills necessary to provide indigent representation, then surely practicing attorneys are capable of the same education. And since pro bono requirements would be a career-long obligation, lawyers would have many years over which to amortize the time invested in obtaining poverty law capability.

If lawyers practicing today are not competent to assist poor people, it is only because it has not been expected of them. Once pro bono obligations become mandatory, the necessary skills would eventually become simply part of being a lawyer. Every state requires lawyers to pass a bar exam, demonstrating at least minimal command of areas where they may well never practice. Aspiring lawyers study for the bar, and most succeed in passing it, notwithstanding their frequent disinterest in, if not out-and-out antipathy for, some or all of the necessary subjects. We see no reason to assume that the overwhelming majority of successful test-takers would do other than apply those same proven educational skills to the mastery of indigent representation.

It can hardly be denied that thousands, perhaps tens of thousands, of lawyers toil daily at tasks they do not particularly enjoy. New associates at large law firms are unceremoniously shuttled off to the library or documents room, to spend their days (and many of their nights) in unfulfilling scut work. ${ }^{277}$ As drudgery-filled as the assignments might be, the great majority of new associates perform adequately, some even feigning enthusiasm. Of course, the potential rewards are great: prestige, income, partnership. ${ }^{278}$ But under a mandatory pro bono plan the rewards would also be great. If not sufficiently motivated by the desire to serve indigents, lawyers at all levels should find ample incentive in the need to maintain their licenses.

${ }^{276}$ See O'Connor, supra note 2, at 4.

277 See YOUNG LAWYERS DIV., AM. BAR ASS'N, THE STATE OF THE LEGAL PROFESSION 1990 , at 52-55 (1991) (concluding that “ [d] issatisfaction has become a major problem throughout the profession" and that the number of lawyers who are dissatisfied with their jobs has increased significantly since 1984); $c$. Thomas D. Morgan \& Robert W. Tuttle, Legal Representation in a Pluralist Society, 63 GEO. WASH. L. REV. 984, 989 n.29 (1995) (asserting that lawyers can and will ably perform even unpleasant duties).

${ }^{278}$ See GALANTER \& PALAY, supra note 113 , at 89-90. 
But lest we be accused of cynicism, let us hasten to add that we fully expect virtually all lawyers to be vigorous, zealous and determined to provide high quality representation to their pro bono clients. Professional ethics require that attorneys act competently; no distinction is made between paying and nonpaying clients. ${ }^{279}$ We take ethics seriously, and we think that the overwhelming majority of lawyers do as well. We trust that attorneys who might deliberately render "half-hearted, shoddy, ineffective service" on pro bono matters are few and far between. ${ }^{280}$

\section{Constitutionality}

There is ample legal and scholarly support for the proposition that mandatory pro bono plans would not violate the Constitution. ${ }^{281}$ Consequently, we will not rehearse those arguments here.

We do note, however, that even the strongest versions of traditional constitutional arguments would be inapplicable to a plan supported by the public-assets theory. Under our analysis, pro bono plans would be initiated precisely to recapture some of the value gained by lawyers through their exploitation of public resources. Thus, such plans are indisputably organized for the purpose of "improving the quality of the legal service available to the people of the State."'282 Moreover, public-assets pro bono programs clearly have the constitutionally permissible effect of requiring "all of the lawyers who derive benefit from the unique status of being among those admitted to practice before the courts [to] be called upon to pay a fair share of the cost of the professional involvement in this effort."

279 See MODEL RULES OF PROFESSIONAL CONDUCT Rule 1.1 (1995) ("A lawyer shall provide competent representation to a client."); MODEL CODE OF PROFESSIONAL RESPONSIBILITY DR 6-101 (1980) (prohibiting a lawyer from "[h]andling a legal matter which he knows or should know that he is not competent to handle").

${ }_{280}$ Marrero Committee Report, supra note 25, at 109.

${ }^{281}$ See, e.g., id. at 114 (stating that "the weight of scholarly and judicial opinion adequately responds to the constitutional challenges"); Rosenfeld, supra note 275, at 286-96 (surveying and rejecting constitutional objections); Silverman, supra note 82, at 948-55 (rejecting most constitutional challenges, but suggesting that a First Amendment objection might have some merit). But see David L. Shapiro, The Enigma of the Lauyer's Duty to Serve, 55 N.Y.U. L. REv. 735 (1980) (arguing that some of the constitutional objections are valid).

${ }_{282}$ Keller v. State Bar, 496 U.S. 1, 14 (1990) (quoting Lathrop v. Donohue, 367 U.S. 820,843 (1961) (plurality opinion)).

${ }^{283} I$ d. at 12. 


\section{TAX OR DRAFT?}

A final question concerning mandatory pro bono obligations is whether they should take the form of a tax or a draft. Should lawyers be required personally to engage in uncompensated representation, or should there be buy-out provisions? The answer to this question is not essential to our thesis; the public-assets theory supports either model. Our conclusion, however, is that the personal service model is preferable.

Proponents of buy-out plans point to one overriding benefit: economy. As Professor Mary Coombs put it:

[T] he poor will benefit more under a plan with a buy-out option than under a straight time obligation, because they will receive either work performed by those who choose to do such work or an equal or larger quantity of services from public interest lawyers funded through monetary contributions. The funds generated by attorneys exercising the monetary option can support other lawyers-providing more legal services-in moderately paid full-time legal services work. Assume, for example, that it costs $\$ 50,000$ a year to support a beginning legal services lawyer... who can provide 2,000 hours in legal work for the poor. The monetary contributions of 12.5 lawyers earning $\$ 200$ per hour would support that lawyer, though they would have directly provided only 250 hours of such services.

In a novel twist on buy-out plans, Professors Galanter and Palay proposed that law firms be allowed to "buy and sell" credits for pro bono work, creating what they called "an effective market in pro bono credits." 285

Inherent in either conception is the vision of idealistic young lawyers cheerfully undertaking the pro bono obligations of their more mercenary elders. Galanter and Palay call them "DoGooder Associates." ${ }^{286}$ In this scenario, everyone wins. Aspiring legal services lawyers receive financial support, disinterested corporate types reserve their time for paying clients, and the poor receive as many (and

${ }^{284}$ Coombs, supra note 81 , at 220 . Timothy Terrell and James Wildman reject the concept of lawyers' personal pro bono responsibility, but not on the basis of economics. They assert that it is the duty of the bar to facilitate pro bono representation, but that no individual should be required to participate (or, presumably, contribute cash) directly. See Terrell \& Wildman, supra note 4, at 428-31. We refuted this position, see supra Part I, when we established the general public assets theory. Terrell and Wildman do not address in detail the "tax or draft" issue.

${ }^{285}$ Marc Galanter \& Thomas Palay, Let Firms Buy and Sell Credit for Pro Bono, NAT'L L.J., Sept. 6, 1993, at 17.

${ }_{286} I d$. 
probably more) hours of representation. But we see two problems. First, it cannot be guaranteed that only committed "do-gooders" will end up shouldering the massive pro bono burden. Second, there is an irreplaceable social value in requiring all lawyers to deal with the problems of the disadvantaged.

Both Coombs's article and Galanter and Palay's essay assume that buy-out funds will be used to support the equivalent of today's legal services offices, staffed by dedicated young lawyers who have chosen indigent representation as a career path. The Galanter and Palay plan explicitly envisions that pro bono providers ("PBPs") will bid for contracts to fulfill other lawyers' obligations. They believe that the PBPs will be composed of "dedicated people with specialized competence in matters that concern the poor."

The introduction of a market, however, suggests a different reality. Let's refer to our establishment, pro bono-avoiding law firm as Rainmaker \& Fee ("R\&F"). Having chosen to substitute money for time, R\&F will obviously tend to contract with the lowest bidders. If "DoGooder Associates" might be willing to fulfill a firm's hourly obligations for a payment of $\$ 150,000$, why wouldn't R\&F try to find an alternative provider who would undertake the same tasks for less, preferably much less. The result would inevitably be a squeeze, as legal services entrepreneurs enter the market and drive down the price. Of course, the surest way to make a profit would be to hire underpaid lawyers, to invest little in training, and to count on high turnover to keep seniority (and salaries) low. Clients would be shortchanged, but poor people receiving free services would hardly be in a position to mount an effective protest.

There is a further difficulty with Galanter and Palay's proposal. They believe that payment to PBPs will result in "more lawyering for the same amount of money, ${ }^{288}$ since their costs will be far lower than those of conventional law firms. As we will demonstrate presently, that is quite unlikely to be the case. Assume, as Galanter and Palay do, that R\&F is composed of thirty attorneys, and has an aggregate pro bono obligation of 1500 hours of service. Now assume that DoGooder Associates offers to fulfill that obligation in exchange for a cash payment of $\$ 150,000$. In Galanter and Palay's model, the DoGooder operation could use that money to support two or three fulltime poverty lawyers, resulting in perhaps 4000 hours of legal services. 
But why would DoGooder Associates choose to provide the additional work for no compensation? Wouldn't they attempt to sell their 2500 hours of excess capacity to another law firm, say, Stahl \& DeLay, to fulfill the obligations of its fifty lawyers?

Galanter and Palay presume that a PBP's efficiencies would be used to generate extra service, but a more palpable incentive would be to generate additional income. And, of course, there is no guarantee that DoGooder would win the reverse auction. Perhaps Don'tCare Associates would undercut their price by offering to do the same work for $\$ 100,000$, in which case the successful bidder would have an even greater incentive to seek out more work from additional firms. Thus, the effect would not be increased services, but rather hour-for-hour substitution of low-price lawyering for high-price lawyering. Law firms, no doubt, would cheer this outcome, but none of the benefit would inure to the poor.

The problem with a market is that it will tend to behave like a market, which makes it a particularly unsuitable device for the delivery of free legal work. The law firms' sole incentive would be to divest themselves of their pro bono duties at the lowest possible expense. The eventual providers' incentive would be to drive down the marginal cost of providing services. Clients, we can all agree, have a stake in quality, but as nonpaying recipients, they would be powerless to enforce their interests, lacking even the ability to take their business to a competitor. Thus, the PBP system would give us all of the worst features of a market, with none of its compensating controls.

If this scenario seems unduly glum, may we suggest that a survey of other service providers in poor neighborhoods would be instructive. It is a well-known phenomenon that furniture stores and used car lots catering to the poor are typically characterized by shoddy merchandise, indifferent service and high prices. Idealism, of course, can overcome this problem, but efficient markets tend to drive out idealists in favor of economizers. That is why medical services in too many neighborhoods are now provided exclusively by low-margin, high-volume, absentee-owned Medicaid mills. ${ }^{289}$

${ }^{259}$ See, e.g., Lynette Holloway, Abortion Doctor Guilty of Murder, N.Y. TMES, Aug. 9, 1995, at Al (reporting that a physician has been convicted of murder in the death of a patient at a clinic that "cut corners for monetary gain at the expense of the lives of its patients, who oftimes were poor and uneducated" (quoting Richard A. Brown, Queens District Attorney)); Illinois' Next Big Medicaid Scandal, CHI. TRIB., May 26, 1996, $\S 1$, at 20 (noting that "bad things can happen when for-profit HMOs ... hustle new members among the poor and undereducated"); Dan Thomasson, Medicare Ripoffs Beg for Reform, ROCKY MOUNTAIN NEWS, Aug. 3, 1995, at 47A (detailing abuses in indigent 
In any event, we believe that a unique advantage is lost once lawyers are given the option of substituting cash for personal services. To state it succinctly, it is too easy for injustice to flourish in courts where the only "customers" are poor people. The presence in those courts of lawyers from all walks of life, even if compelled, would give elite members of the bar an interest and a stake in the operation of those courts. One of us previously published a memoir illustrating this principle, which we now recount in full:

For two years after I graduated from law school, I worked in a legal services office on Chicago's west side. From my first day on the job I became our office's "consumer law expert," which required me to spend considerable time in the courtrooms on the eleventh floor of the civic center. While the words "eleventh floor" are unlikely to evoke a phobic reaction from lawyers outside of Chicago, anyone who ever practiced there will recognize immediately the terrible scene that I am about to describe.

In the early 1970s the eleventh floor was a no-man's land for poor people. It housed the landlord-tenant and collection courts, and therefore saw an endless stream of hapless individuals come before the bench to be processed. The all but inevitable outcome of every case was either an eviction or a wage garnishment. The plaintiffs' bar ran the courtrooms, to the point that these lawyers virtually organized the judges' calendars. The defendants were almost always unrepresented. If they had defenses, they had no way of recognizing or raising them. The best result that a defendant could hope for, whether liable or not, was usually a few extra days in his or her apartment or a few extra months to pay a debt.

The worst feature of the eleventh floor, however, was not the judgments that were entered. The worst feature of the eleventh floor was the way that the defendants were treated. The judges were nasty and peremptory. They rushed through the cases without allowing the defendants to talk, and they ridiculed defendants who attempted to say a few words in their own behalves. The clerks and bailiffs were worse, refusing to answer questions or to give explanations. The only advice they would give was "sit down and wait until your case is called." A defendant who stepped out to the washroom ran the risk of a default judgment, although cases could be "held" for hours if the plaintiff's attorney was busy elsewhere.

Every courtroom on the eleventh floor seemed to operate in continual bedlam. The plaintiffs' attorneys were always huddled and talking to each other. The clerks were always shouting orders to the ill-fated defendants. The judges were always barking out their judgments-seven days to move, thirty days to pay, add on the attorney's fees, and do not

medical delivery, including "Medicaid mills, laboratory scams ... and prescription fraud"). 
ask any questions. To me, the noise represented the character of the entire place; I thought of it as the din of injustice.

Legal services lawyers were seen as interlopers, people who wanted to ruin everyone else's easy time. We were tolerated, but just barely. I think that the judges considered us to occupy a position about half a step higher than the indigent defendants. These were courtrooms badly in need of reform.

Then one day, when I was sitting in one of the worst courtrooms waiting for my daily portion of judicial abuse, it happened. A pinstriped, downtown lawyer walked up to the bench and said, "Your Honor, I would like to present Mr. Albert Jenner." In 1975, the late Albert Jenner was probably the most well known and widely respected lawyer in Chicago. A name partner in Jenner \& Block, he was most famous as the Republican counsel to the Senate Watergate Committee. Many believed that $\mathrm{Mr}$. Jenner was the man most responsible for the eventual committee vote to impeach President Nixon. His visage-stern countenance, ramrod posture, piercing eyes, and signature bow tie-was well known to every Chicagoan who owned a television set. Albert Jenner was a man of unrivaled prominence, integrity, and power, and he had apparently come to the eleventh floor as a favor to a friend or employee.

Once Mr. Jenner's presence was announced, the entire courtroom suddenly metamorphosed. The muttering plaintiff' bar fell silent. Clerks began answering inquiries from unrepresented defendants. The judge actually asked questions about the facts and the law. It was as though we were now in a real courtroom where justice, and people, mattered. Furthermore, this effect lasted for the entire day, long after Mr. Jenner left.

More than anything else imaginable, the unexpected presence of an important lawyer recast procedures on the eleventh floor. The judges and court personnel began to worry about how they appeared. Instead of facing only disinterested regulars and perceived no-accounts, they now had to be concerned about the well-to-do and powerful. For the rest of that day it was possible to practice law on the eleventh floor as though we were in a real courtroom.

By the next week, unfortunately, the residual effects of Mr. Jenner's visit had worn off. The clerks and judges were back to their old, short-tempered selves. Occasionally, however, even they seemed to long for the dignity and status that comes with procedural regularity; they bragged, as though it reflected honor upon them, of the time that "Bert Jenner handled a case in our courtroom."

The lesson here is equally applicable to Professor Coombs's traditional proposal and to Professors Galanter and Palay's market-based approach.

${ }^{290}$ Steven Lubet, Professionalism Revisited, 42 EMORY L.J. 197, 204-06 (1993) (footnote omitted). Another version of this story appeared under the unfortunate title Prominence Counts in Pro Bono Appearances, NAT'L. L.J., Oct. 4, 1993, at 15. 
The presence of a prominent lawyer can have a transformative effect on a courtroom. And there are many courtrooms that are in serious need of transformation. While the eleventh floor of the 1970s might have been unique in its combination of clerical squall and juridic torpor, there are numerous others today that differ only as a matter of degree. Eviction courts, collection courts, traffic courts, juvenile courts and misdemeanor courts everywhere would all no doubt benefit from a healthy dose of public exposure.

Imagine the effect, then, if on any given day some contemporary equivalent of Albert Jenner were likely to walk into any given courtroom. Best behavior would become a constant, rather than an aberrant, occurrence. The norms of process would change for the better. There could be no more dirty little secrets or comfortable procedural shortcuts, since missteps would now run the risk of offending someone capable of requital. ${ }^{201}$ We do not see the presence of important lawyers as a panacea, but their involvement with poor people would be a worthwhile first step. ${ }^{292}$

The public-assets theory establishes a social claim on lawyers' resources, by virtue of their utilization of publicly created goods. The most robust version of this claim would require direct, in-kind services by members of the bar. This approach is merited first because it requires the return to the public of precisely the same form of capital as lawyers exploit on behalf of their paying clients, and second because it multiplies the benefits to the social order in a form that could not be accomplished otherwise.

\section{CONCLUSION}

We have presented here our initial effort at developing a comprehensive statement of lawyers' pro bono obligations. Unlike previous accounts, our theory does not depend upon appeals to need or moral duty, nor is it premised upon the asserted existence of a factually questionable monopoly.

We understand that our theory is novel, and therefore not com-

${ }^{291}$ Lubet, supra note 290, at 207.

292 Galanter and Palay reject this argument, referring to it as reflecting "a childlike faith that we will be saved by Big Daddy." Marc Galanter \& Thomas Palay, We Don't Need Superstars to Do Pro Bono, NAT'L L.J., Dec. 13, 1993, at 14. We think that our point is more sophisticated. Institutions respond to power. For better or worse, prominent lawyers hold power in a way that is not soon likely to be duplicated by pro bono providers, whether motivated by idealism or mercantilism. Hence, the required presence of big shots may lead to systemic reform. 
pletely developed. For example, we have not been able to locate the appropriate number of pro bono hours, other than to posit that it probably lies between 20 and 50 hours per year. ${ }^{293}$ We are also not fully satisfied with our discussion of other uses of public assets in different contexts; we believe that our examples are informative, but we acknowledge that they are not entirely comparable to law practice.

We are confident, however, in our central insight that secrecy (or perhaps the assurance of secrecy) is a commodity-established by public means, but exploited enthusiastically by lawyers and their clients. Hence, our observation that attorneys as a class benefit financially from their access to and sale of public assets. The exaction of a defined number of pro bono hours, therefore, is an appropriate inkind commission taken in consideration of lawyers' profitable utilization of publicly created resources.

${ }^{293}$ In other words, between $0.75 \%$ and $2 \%$ of the typical lawyer's annual billings. See supra note 26 . In fact, since lawyers necessarily work more hours than they bill, the actual impact on their working time would be even less. 
